\title{
U norden
}

Trends and drivers of change in diving ducks

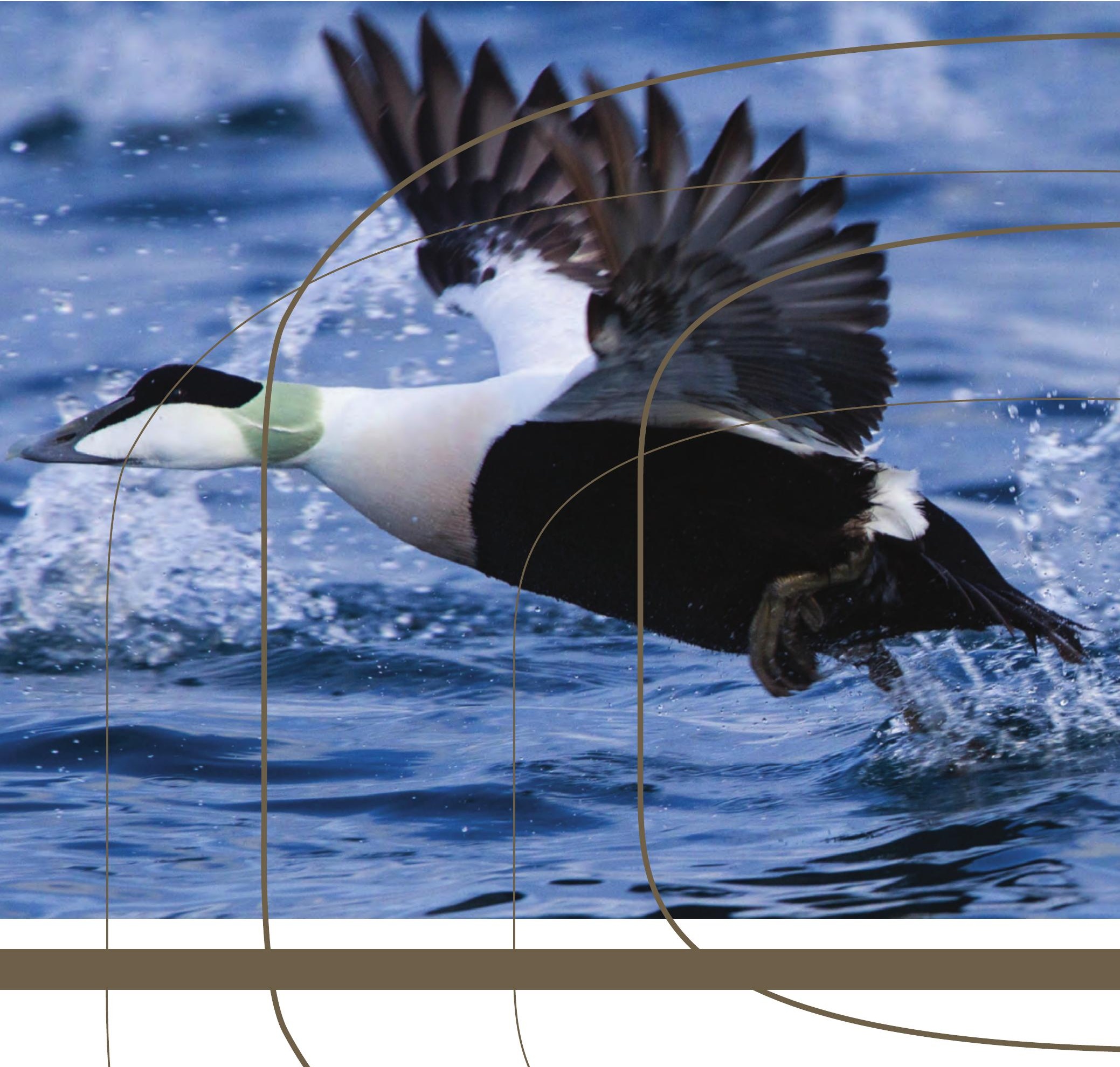



norden 



\section{Trends and drivers of change in diving ducks}

Mikael Kilpi, Svein H. Lorentsen, Ib K. Petersen and Arni Einarsson 
Trends and drivers of change in diving ducks

Mikael Kilpi, Svein H. Lorentsen, Ib K. Petersen and Arni Einarsson

SBN 978-92-893-3979-7 (PRINT)

ISBN 978-92-893-3981-0 (PDF)

ISBN 978-92-893-3980-3 (EPUB)

http://dx.doi.org/10.6027/TN2015-516

TemaNord 2015:516

ISSN 0908-6692

(C) Nordic Council of Ministers 2014

Layout: Hanne Lebech

Cover photo: Ron Knight from Seaford, East Sussex, United Kingdom

Print: Rosendahls-Schultz Grafisk

Printed in Denmark

Copies: 100

This publication has been published with financial support by the Nordic Council of Ministers. However, the contents of this publication do not necessarily reflect the views, policies or recommendations of the Nordic Council of Ministers.

www.norden.org/en/publications

\section{Nordic co-operation}

Nordic co-operation is one of the world's most extensive forms of regional collaboration, involving Denmark, Finland, Iceland, Norway, Sweden, and the Faroe Islands, Greenland, and Åland.

Nordic co-operation has firm traditions in politics, the economy, and culture. It plays an important role in European and international collaboration, and aims at creating a strong Nordic community in a strong Europe.

Nordic co-operation seeks to safeguard Nordic and regional interests and principles in the global community. Common Nordic values help the region solidify its position as one of the world's most innovative and competitive.

Nordic Council of Ministers

Ved Stranden 18

DK-1061 Copenhagen $\mathrm{K}$

Phone (+45) 33960200

www.norden.org 


\section{Content}

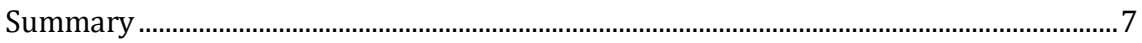

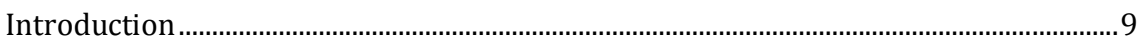

1. Wintering populations of the focal species ................................................................ 13

1.1 Delineation of focal area(s) .......................................................................... 13

1.2 Characterization of importance of the Baltic Sea by species and breeding region ......................................................................................... 13

1.3 Regional importance of regions of the Baltic Sea for wintering

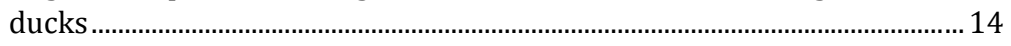

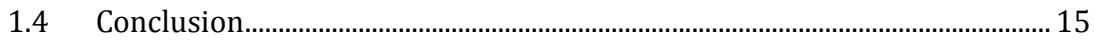

2. Trends of wintering populations of the focal species .............................................. 17

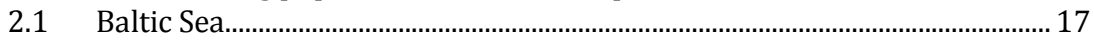

2.2 Winter populations on the Norwegian coast.................................................... 20

2.3 Conclusions.................................................................................................... 24

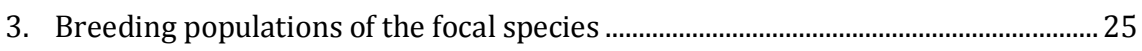

3.1 Short presentation on numbers and trends in all countries.......................... 25

3.2 Overall conclusions........................................................................................... 31

4. Details on national declines in coastal populations of the focal species in

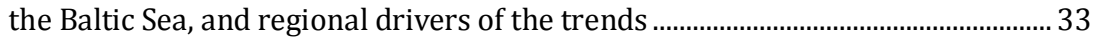

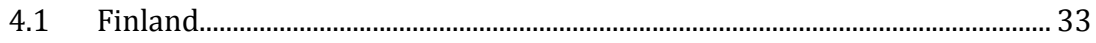

4.2 Common Eider......................................................................................................... 33

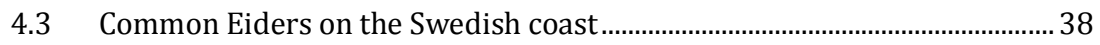

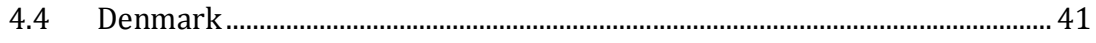

4.5 Norwegian and Icelandic Common Eiders ...................................................... 42

5. Working for the future .......................................................................................... 43

5.1 Answers to basic questions: are data from current monitoring sufficient to verify trends? ................................................................................ 43

5.2 How can we be more effective in establishing trends?................................... 44

5.3 The state of knowledge about the drivers of the negative trends ................ 44

References ..................................................................................................................... 49

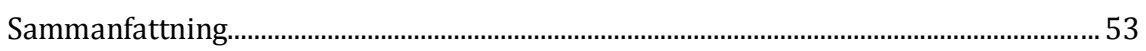

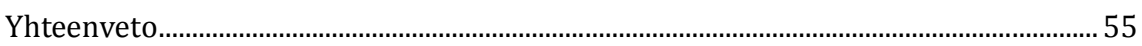





\section{Summary}

This report summarizes the recent trends in five species of diving ducks breeding in, or wintering within, the Baltic Sea, and compares trends verified with trends outside the Baltic Sea, in Norway and Iceland. The focal species are Greater Scaup (Aythya marila), Common Eider (Somateria mollissima), Long-tailed Duck (Clangula hyemalis), Common(Melanitta nigra) and Velvet Scoter (M. fusca). All focal species have recently been reported to decline rapidly in winter in the Baltic Sea, and they all feed on mussels, to a large extent on Blue Mussels (Mytilus edulis $x$ M. trossulus).

The trends for breeding birds within the Baltic Sea area verify rapid and steep declines for Greater Scaup, Common Eider and Velvet Scoter in coastal populations in Finland and Sweden. Danish Eider have stable populations, while outside the Baltic Sea, Norwegian breeding Common Eiders are largely declining, while Icelandic Common Eiders seem to have stable populations. Coastal populations of both Greater Scaup and Velvet Scoters are generally small, and especially the Greater Scaup has nearly disappeared from coastal areas.

Inland breeding populations of Greater Scaup, Long-tailed Ducks and Common Scoters in Finland and Sweden seem to be stable or increasing, but these populations are small. Inland Velvet Scoters in Sweden are likely decreasing. No national monitoring of other species than breeding Eiders is carried out in Norway and Iceland.

The recent declines of the wintering populations in the Baltic Sea of these species reported by Skov et al. (2011) identified decreases in the range of 50\% for all species between two time periods (1988-1993 and 2007-2009), with a decline by 65\% in the Long-tailed Duck representing the most striking decline. Largely wintering trends in Norway parallel the general trends in the Baltic for Long-tailed Ducks and Common Eiders, while the trends for Greater Scaup (very small wintering population), and both species of Scoters are less clear.

Albeit there are possible difficulties in interpreting the data used in the assessment of Skov et al. (2011), the generality of the trends seem quite robust, and are also backed up by trends in breeding birds using the Baltic Sea. For the Long-tailed Duck, also other data exist to back up the recent decline (Bellebaum et al. 2014). The report by Skov et al. 
(2011) also gives useful data on spatial distribution of the wintering populations which can be used for improving the monitoring of the birds, and also for pin-pointing where efforts on both research and management, and on the state of the wintering areas would most effectively be located. Such efforts should be multi-national and fully coordinated. It is also reasonably clear, that the trends call for research tailored for mitigation measures.

The national monitoring programs for the species all point to a need for some revision of the routines used. This concerns birds in both coastal and inland breeding habitats. It is, however, reasonably clear that the trends identified in existing monitoring schemes are validated enough, and further action on especially coastal populations of Greater Scaup, Common Eider and Velvet Scoter are badly needed.

When trying to identify the drivers for the observed declines of breeding ducks in the Baltic Sea area, it becomes clear that next to nothing is known in the case of the Greater Scaup and the Velvet Scoter. Existing data on Common Eiders strongly suggests that in Finland and possibly also Sweden, efforts to identify the effects of increasing predation by increasing populations of White-tailed Sea Eagles (Haliaeetus albicilla) should be seriously considered. Ways to minimize the effects of predation should be considered, as it appears at least in Finland to be a main driver of the Common Eider decrease. Also, there is a clear need to revise the monitoring schemes by including data on vital rates (productivity and mortality) at least in the core breeding areas. Also on a longer perspective, possible effects of other drivers related to changes in food webs affecting the primary food of the birds may need to be studied further. Further, attention should also be paid to detailing the drivers of decrease in Norwegian Common Eiders populations, and coordinating monitoring efforts done on the Åland Islands (autonomous part of Finland) with the national Finnish monitoring schemes.

Monitoring of wintering birds would benefit from multi-national coordination of survey efforts, and should in the future also focus on identification of the core wintering areas, and a better coverage of the entire Baltic Sea. For wintering birds, there is also a pressing need to identify the state of the core wintering area for each species, with respect to the staple food resources. In a rapidly changing world, we should also pay attention to the fact that birds may shift into new areas as they become available (c.f. Lehikoinen et al. 2013). 


\section{Introduction}

The publication of the report on the population status of waterbirds wintering in the Baltic Sea (Skov et al. 2011, Waterbird Populations and Pressures in the Baltic Sea, TemaNord 2011:550) highlighted a rapid decline in a number of seaduck species wintering in the Baltic Sea, including Greater Scaup (Aythya marila), Common Eider (Somateria mollissi$m a$ ), Long-tailed Duck (Clangula hyemalis), Common Scoter (Melanitta nigra) and Velvet Scoter (M. fusca). While these species are not exclusive examples of declines reported, these seaducks are numerically very dominant among the wintering birds, and all feed mainly on mussels, such as Blue Mussels (Mytilus edulis x M. trossulus). This common feature in the ecology of these ducks, generates a second central question on possible changes in the abundance of their preferred food reflecting changes in the Baltic Sea food chains on a more general level (e.g. Ottwall 2012).

The recent Red List of HELCOM (HELCOM, 2013: HELCOM Red List of Baltic Sea species in danger of becoming extinct. Balt. Sea Environ. Proc. No. 140.) identifies wintering Common Eider, Long-tailed Duck, Common- and Velvet Scoter among the species of concern in the Baltic Sea, and also highlights the status of breeding Greater Scaup, Common Eider and Velvet Scoter (Baltic coastal populations).

Skov et al. (2011) contrast in the case of the wintering seaduck populations two estimates (1988-1993, 2007-2009) and report a decrease in of Long-tailed Duck of 65\% (recent winter population about 1.5 million birds), 56\% for Velvet Scoter (population 415,000), 51\% for Common Eider (population 515,000), 48\% for Common Scoter (population 410,000 ) and $13 \%$ for Greater Scaup (population 127,000). These estimates have been widely cited (Ottwall 2012), owing to the fact that the importance of the Baltic Sea as a non-breeding wintering area for these species is great, since for these species the majority of the entire northwest European bio-geographical breeding population use the Baltic Sea. Thus, more than $90 \%$ of all breeding Long-tailed Ducks and Velvet Scoters of the total north-west European (including north-west Russia, Delany \& Scott 2006) bio-geographical populations use the Baltic Sea, and about $50 \%$ of the populations of the other three species. 
Changes in the breeding populations of these species in the Baltic Sea, or in other habitats close to the Baltic Sea have also recently been identified as showing rapid declines. In particular, concern has been raised on the state of the Common Eider population of the Baltic (Ekroos et al. 2012a). Ekroos et al. (2012a) show that particularly in Sweden and Finland, Common Eider populations have halved during the 21th century. This is of great concern, since the majority ( $>80 \%$ in 2000) of the entire Baltic/Wadden Sea flyway population breed in Sweden and Finland.

For the other breeding species, there is considerably less information available (see HELCOM 2013), and the total breeding populations for Greater Scaup, Common- and Velvet Scoters and Long-tailed Ducks are comparable small, and therefore represents smaller fractions of the flyway populations.

The high rates of decline of both wintering and breeding populations of the species dealt with here are alarming primarily because of the speed of the decline. The life-histories of the species on a very general level (long-lived birds with comparably low rates of reproduction, see Wilson et al. 2012) could indicate that very profound changes in either the breeding areas and/or the wintering areas affecting vital rates (reproductive success and juvenile and adult survival) have taken place. Hence it is important to assess the accuracy of the trends. This also highlights a need to assess the monitoring systems used in the focal area focusing on accuracy and possible inadequacies of monitoring breeding and wintering populations on both national and larger scales (see Naturvårdsverket 2013, Övervakning av sjöfåglar, Regeringsuppdrag till Naturvårdsverket RB 2013, Skrivelse 29.8.2013).

Since the trends for the focal species, both concerning breeding numbers and wintering numbers, have been perceived as alarming, there is obviously also a pressing need to assess if data on the causal reasons for the declines are comprehensive, and if, on what level of detail. In a compilation of available data (Ottwall 2012), a number of reasons for the decline have been identified especially for the case of the Common Eider. This particular case is a tangled web of explanations of mixed generality, since Common Eider decline is not uniform in different parts of the breeding- or wintering area, and possible causative agents also do not show a well-defined pattern over larger parts of the breeding- or wintering range. Here we try to disentangle available evidence, and point to possible large-scale causations.

Clearly, if we are able to point out reasons for the decline, we also need to address mitigation measures, and point out what we might be able to do, as has been previously summarized by Ottwall (2012). 
We also address another dimension of the case of the declining Baltic seaducks, and make a larger comparison with other populations both breeding and wintering outside the Baltic Sea. Using data from populations in Norway and on Iceland we look for similarities and dissimilarities and put them in context with the Baltic case. One of the key questions here is that there may be differences in trends found outside the focal areas, and if such differences are found, they may help us in understanding the Baltic/Wadden Sea flyway case. 



\section{Wintering populations of the focal species}

\subsection{Delineation of focal area(s)}

We follow the delineation of the Baltic Sea (henceforth) wintering area by Skov. et al. 2011), including Kattegat and bordering the North Sea at the northern tip of Jutland, Denmark. This area may also be defined as the HELCOM area (see HELCOM 2013). The total area of the Baltic/Wadden Sea flyway is, however, larger, including the Wadden Sea and other areas on the North Sea / Atlantic coast. Other areas (Norway, Iceland) are mentioned when appropriate. The wintering areas of Norwegian and Icelandic species are indicated as appropriate.

\subsection{Characterization of importance of the Baltic Sea by species and breeding region}

The Baltic is used by all focal species. Skov et al. (2011) use the total north-western European wintering population estimates as presented by Delany \& Scott (2006) as basis for judging the importance of the Baltic Sea for populations of the species. The importance index used below is based on the size of total biogeographical wintering population of the flyway (assessed basically in 1996) and the calculated Baltic Sea wintering population 1988-1993 as the fraction of the Baltic winter bird numbers of the total wintering population. Updates of population estimates can be obtained at the Wetlands International home pages. Other characterizations of the origin of the birds used here follow the report of Naturvårdsverket (2013) and other sources mentioned below.

The vast majority of the Velvet Scoters of the flyway population arrive from Russia, of which the bulk (93\%, Skov et al. 2011) winters in the Baltic. The coastal populations from Sweden and Finland use the Baltic area, Norwegian birds winter off Norway (see also Saurola et al. 2013).

The vast majority of the wintering birds of Long-tailed Ducks arrive from north Russia (ca. $90 \%$ of the bio-geographical population, Skov et al. 2011). The small populations breeding in Sweden and Finland may 
overwinter off the Norwegian coast (see also Saurola et al. 2013), as do Norwegian breeding birds.

The majority (58\%, Skov et al. 2011) of Common Eiders of the biogeographical population winters in the Baltic (given as 35\% Table 27 of Skov et al. (2011)). Breeding birds from the coasts of Finland and the east coast of Sweden (and other parts of the Baltic Sea breeding area) spend their winter off the coast of eastern Jutland. Eiders from the Swedish west coast and southern Norway reach the Kattegat area (Noer 1991). The majority of wintering Norwegian Eiders do not use the Baltic Sea. The northernmost Swedish and possibly Finnish coastal breeding birds (Bothnian Bay) may winter off the Norwegian coast. Icelandic Eiders are sedentary.

Half of the (49\%) Common Scoters from the entire bio-geographical population breeding mostly in Russia use the Baltic Sea in winter. Possibly northern Swedish and Finnish breeding birds winter off the Norwegian coast. A smaller fraction of the breeding Norwegian birds may winter on the Norwegian coast.

Nearly half of the bio-geographical population of Greater Scaup, most of which breed in Russia, use the Baltic during winter. Some birds winter off the southern Norwegian coast. Ring recoveries of coastal Finnish breeding Scaup (Saurola et al. 2013) indicate that some of the birds also use the Baltic Sea.

\subsection{Regional importance of regions of the Baltic Sea for wintering ducks}

Detailed maps of the distributional "hot-spots" for each of the focal species wintering in the Baltic can be found in Skov et al. (2011), and will not be reproduced here. These "hot-spots" are characterized by high densities of birds. Data for identification of these areas was obtained from surveys aimed at finding the relatively most important areas for each species. Skov et al. (2011) used land-based counts, aerial total counts, aerial transect counts and ship-based transects. The characterizations below assume that these densities approach a reasonable accuracy. This approach is discussed later on in the report.

The most important areas for Velvet Scoter are clearly the Pomeranian Bay and the Irbe Strait-Gulf of Riga.

Long-tailed Ducks use three different areas, the Pomeranian Bay, the Irbe Strait-Gulf of Riga area and Hoburgs Bank-Midsjö Bank. 
For Common Eiders, wintering is fairly well localized around the Kiel Bay-Little Belt-South Funen region.

The Common Scoter winter distribution is fairly well limited in the north-west Kattegat area.

The most important areas include for Greater Scaup the south-west Baltic (Szczecin Lagoon, Usedomer and Greifswalder Lagoon).

The habitat of each high-density area is characterized by Skov et al. (2011). The most important spatial units with high densities and high number of birds may be the most useful units for monitoring and management, unless shifts in distribution occur.

\subsection{Conclusion}

The Baltic Sea is by far the most important wintering area for the biogeographic population of both the Common Scoter and the Long-tailed Duck. The importance for the other species may be judged as high as well. Clearly, as the area used during winter in some species in northwestern Europe is very large (such as in the Common Eider), the importance of the Baltic Sea for the entire population decreases

For species breeding in the Baltic Sea, such as the Common Eider, the importance of the Baltic Sea is enhanced as the entire life-span of a bird is spent within the Baltic. Equally, for Baltic Velvet Scoters the importance of the Baltic is judged as high.

The Baltic clearly has no importance for Icelandic birds, and for most populations of the focal species breeding in Norway.

Possible consequences of using spatially distinct parts of the Baltic Sea by breeding birds of the focal species will be discussed later. 



\section{Trends of wintering populations of the focal species}

\subsection{Baltic Sea}

The wintering populations of all five focal species in the Baltic have reportedly declined between 1987 and 2009 (Skov et al. 2011). The recent results rely on data from surveys performed in 2007-2009, which were compared to data collected in 1992-1993 (Durinck et al. 1994). These surveys aimed at obtaining densities of birds, i.e. to identify the relatively most important areas for each species using land-based counts, aerial total counts, aerial transect counts and ship-based transects. Estimated population sizes from these data were made by integrating density estimates for discrete areas of different density levels. Further, to assess changes in numbers, these were compared with the previous density data created by Durink et al. (1994). Thus, the large-scale decreases of wintering seaducks are based on two large-scale surveys of the birds both producing a total estimate of the population size, which are compared.

The most severe large-scale reduction in the wintering population, that of the Long-tailed Duck was reported to be $65 \%$, with smaller and more geographically determined changes for Common Eider, Common Scoter, Velvet Scoter and Greater Scaup.

The result in Skov et al. (2011) may, however, be biased, because (1) the estimates of the total numbers from 2007-2009 are modelled from a heterogeneous set of data. At the same time (2), the estimates of densities from the 1992-1993 surveys are described as being "relative densities", a phrase used to indicate that, while the relative distribution of the species in question may be sufficiently described, the uncertainties in the estimation of total numbers may be considerable.

Both survey reports (Durink et al. 1994, Skoev et al. 2011) are thus based on a mixture of aerial and boat survey methods analysed using relatively opaque modelling techniques, especially in the earlier survey period. 
The latter report (Skov et al. 2011), however, states that:

"the almost complete lack of quantitative data on waterbirds wintering in the offshore areas has made it virtually impossible to track changes in populations of wintering seaducks, divers and grebes, including the numerically and ecologically dominating seaduck species like Long-tailed Duck, Velvet Scoter and Common Scoter."

As a consequence, there is an element of uncertainty in the derived total population produced, and hence the judgement of the magnitude of the decline may be uncertain.

Apart from these two large population estimates (Skov et al. 2011) so widely cited and used as reflecting a drastic decline in the focal species, Skov et al. (2011) also perform a trend analysis based mainly on landbased counts covering the period 1987-2008. The land-based counts may not actually (also stated in Skov et al. 2011) reflect the..."true development of the wintering population...", especially in the case of Common Eider, Long-tailed Duck, Velvet Scoter, with a better fit for Common Scoter and still high uncertainty for the Greater Scaup.

Another assessment (Ekroos et al. 2012a) of the wintering population size of the Common Eider in the Baltic Sea gave a general scenario contrasting with the results of Skov et al. (2011). Using national midwinter census data (see Desholm et al. 2002), the results in brief suggest that roughly 1.2 million birds wintered in 1990. In 2000, the population would have gone down to 760,000, only to rise again in 2009 to almost 980,000 birds, paralleled by a decline of birds wintering in the Wadden Sea. The result suggest that no real decline took place in the period covered in the large-scale comparison by Skov et al. (2011), instead the decline was only $17 \%$.

Ekroos et al. (2012a) state that:

"our ability to count birds on the wintering grounds with sufficient accuracy to detect a change between 2000 and 2009 may be compromised, complicated by the shift in to more accurate census methods (Denmark) and better coverage (in Germany). If so, the recent apparent increase in midwinter numbers reported here may not reflect a real change in abundance."

The results in Ekroos et al. (2012a) also show that the number of breeding Common Eiders in the Baltic Sea dramatically declined by $48 \%$ from 2000 to 2009 . The estimated number of breeding pairs on the flyway in 2000 was 561,000 , and 291,000 in 2009 . This translates roughly into a potential winter population of 1.1 million adult birds in 2000 and 580,000 in 2009. The winter population estimate is accordingly too low 
in 2000, and far too high in 2009, given that not only adult birds constitute the winter population.

Therefore, it seems that reliability in large-scale population estimates may not be easy to achieve, and caution in interpretation of change is always needed.

If this is the case, and if (1) concern is raised about the declining species, which is called for irrespective of the failure of detecting an absolute change in number, we clearly need (2) to revise the way monitoring of seaducks offshore is done in order to improve both coverage and accuracy. Ekroos et al. (2012a) consider unified and coordinated flyway-scale winter counts as a top priority to ensure that national winter surveys also would generate more reliable fly-way level population estimates.

Although seaducks that feed on benthic food sources are to a large extent faithful to their wintering sites, they are also opportunists, and will switch to new areas when these become available, which suggests that shifts in wintering area can also be over large distances. This may well be the case for Common Scoter wintering in Denmark, where there have been shifts from inner Danish Baltic Sea waters to the Danish North Sea (outside the Baltic, Petersen \& Nielsen 2010).

New surveys of the Kola/White Sea show increasing numbers of Steller's Eider (Polysticta stelleri) overwintering, probably caused by milder climate and greater extent of ice free areas closer to their breeding grounds (Aarvik et al. 2013). Consequently, numbers in Norway further west have dropped (Zydelis et al. 2006). Such shifts cannot be eliminated, and such changes in wintering range likely contribute to "local" declines in the Baltic. Whether similar patterns could be true for Longtailed Duck is uncertain.

This calls for a more flexible and proactive monitoring of the offshore birds.

The indications of low reproduction rates for Long-tailed Duck reflected in few young birds on the wintering grounds (K. Larsson, pers. comm.) as well as indications of reduced breeding densities in areas of the Russian breeding grounds call for concern. The true magnitude of population decline maybe unclear, but nonetheless indicates a serious problem. It is also important to realise, that doing accurate and good monitoring of the Long-tailed Duck on its primary wintering grounds in the Baltic also may help us to find ways of ensuring the well-being of the species outside the breeding range. This is also true for the segments of the wintering populations of all other focal species, of which the bulk breed elsewhere. 


\subsection{Winter populations on the Norwegian coast}

The following section gives a brief overview of trends in wintering populations of the focal species off the Norwegian coast. Most sites where monitoring of Norwegian birds is performed, are well outside the Baltic Sea area. The Norwegian population monitoring of wintering (sea) birds has quite good coverage along the coast and is assumed to give a good and representative view of the development of the wintering populations.

For the Velvet Scoter the annual indices are highly variable, however, the national trend suggests that the wintering population is quite stable on both short- and long-term (Table 1, Fig. 1).

Table 1: National trends for wintering Velvet Scoter in Norway

\begin{tabular}{lrrrrr} 
Area & Period & Number of years & Annual change (\%) & Trend & P \\
National & $1980-2011$ & 32 & -0.79 & $0(-)$ & 0.551 \\
& $2002-2011$ & 10 & 1.55 & $0(+)$ & 0.333 \\
\hline
\end{tabular}

The table lists time period for the counts, number of years with counts within the time period, annual population changes (\%), trend (+/0/-) and the level of significance for the estimated trend calculated using Monte Carlo simulations.

Fig. 1: National trend for wintering Velvet Scoter in Norway

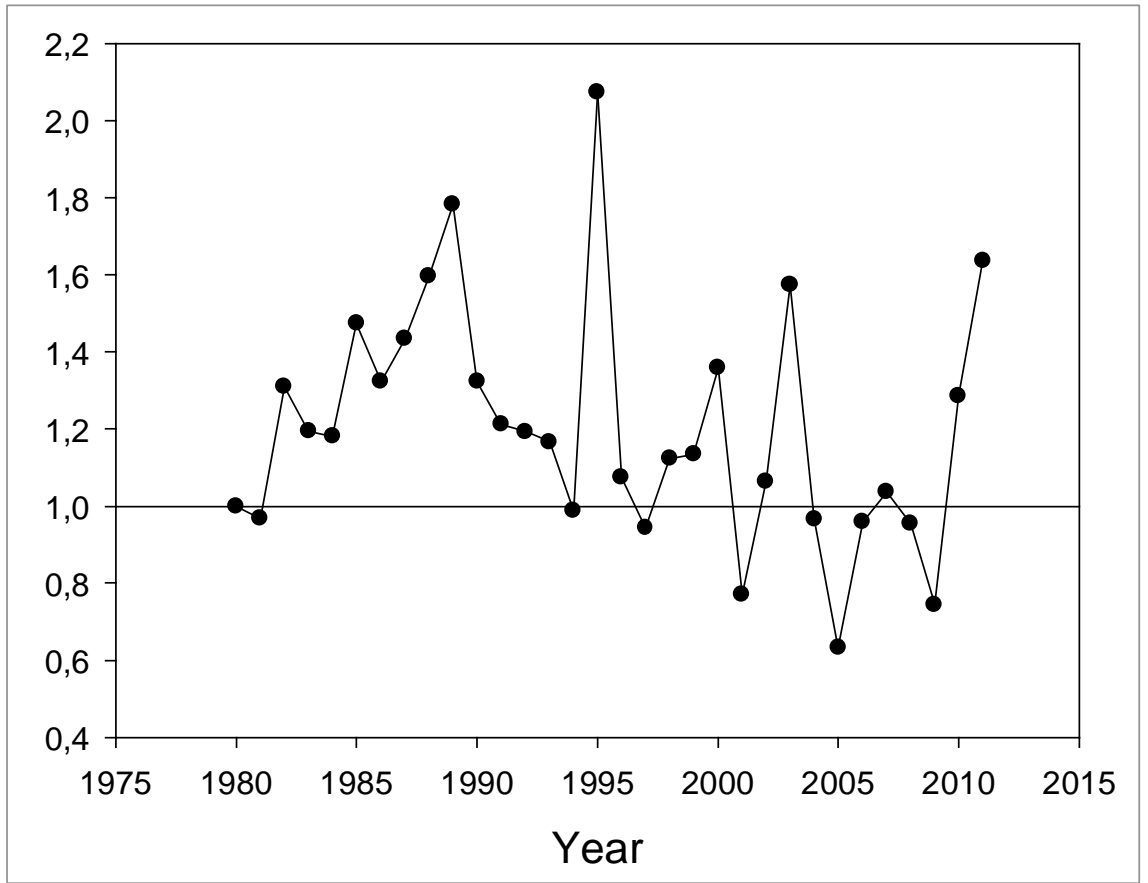


Long-tailed Ducks wintering off the Norwegian coast show a clear longterm trend which is negative for the period 1980-2011, indicating a rapid decrease between 1990 and 2005 (Table 2, Fig. 2).

Table 2: National trends for wintering Long-tailed ducks in Norway

\begin{tabular}{lrrrrr} 
Area & Period & \# years & $\begin{array}{r}\text { Annual change } \\
\text { (\%) }\end{array}$ & Trend & P \\
\multirow{2}{*}{ National } & & & & & \\
& $1980-2011$ & 32 & -2.84 & - & 0.023 \\
& $2002-2011$ & 10 & 5.63 & $0(+)$ & 0.188 \\
\hline
\end{tabular}

The table lists time period for the counts, number of years with counts within the time period, annual population changes (\%), trend (+/0/-) and the level of significance for the estimated trend calculated using Monte Carlo simulations.

Fig. 2: National trend for wintering Long-tailed Ducks in Norway

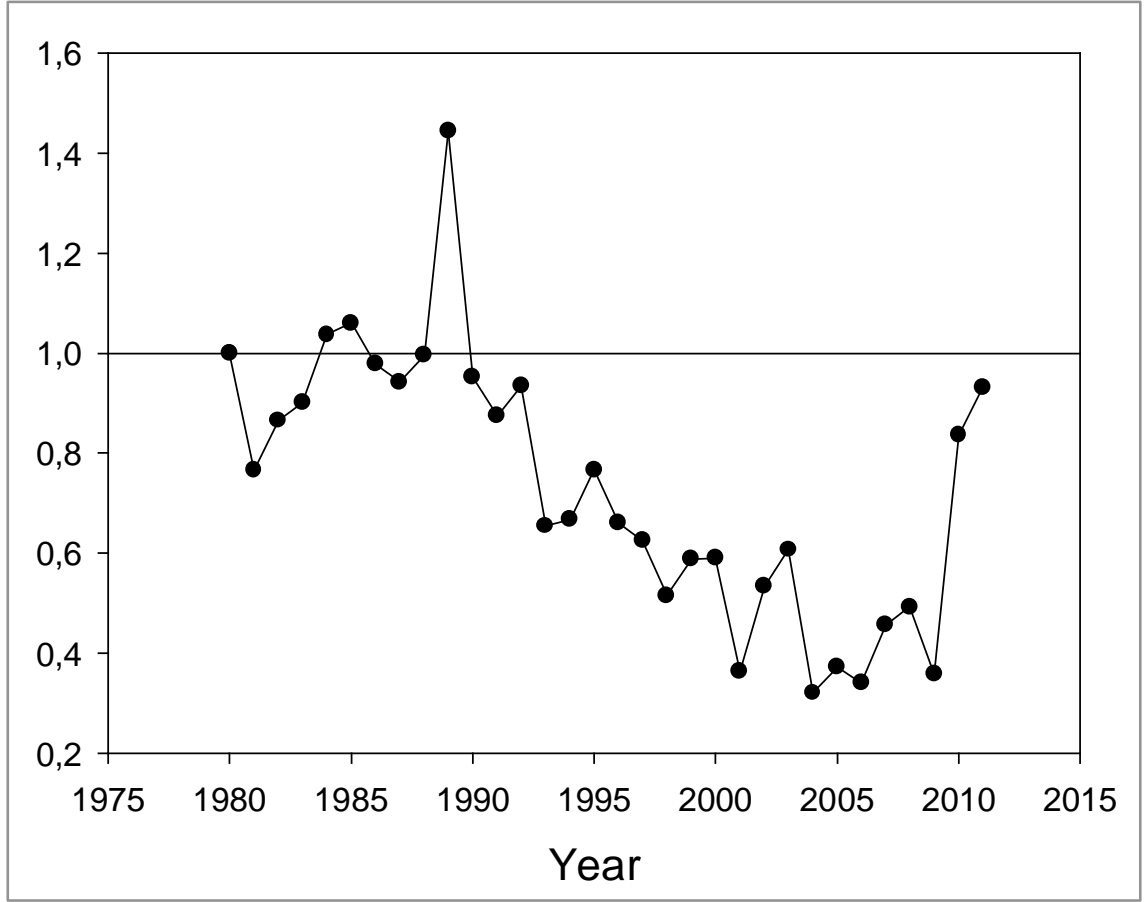

The national trend for wintering Common Eiders in Norway show a negative long-term trend (1980-2011), but the trend for the last 10 years (2002-2011) area stable (Table 3, Fig. 3). The long-term, negative, population development has been particularly pronounced for the coast between Central Norway (Trondheimsfjorden) and northwards to Lofoten. 
Table 3: National trends for wintering Common Eider in Norway

\begin{tabular}{lrrrrr} 
Area & Period & Number of years & Annual change (\%) & Trend & P \\
National & $1980-2011$ & 32 & -2.9 & - & 0.002 \\
& $2002-2011$ & 10 & 0.87 & $0(+)$ & 0.311 \\
\hline
\end{tabular}

The table lists time period for the counts, number of years with counts within the time period, annual population changes (\%), trend (+/0/-) and the level of significance for the estimated trend calculated using Monte Carlo simulations.

\section{Fig. 3: National trend for wintering Common Eiders in Norway}

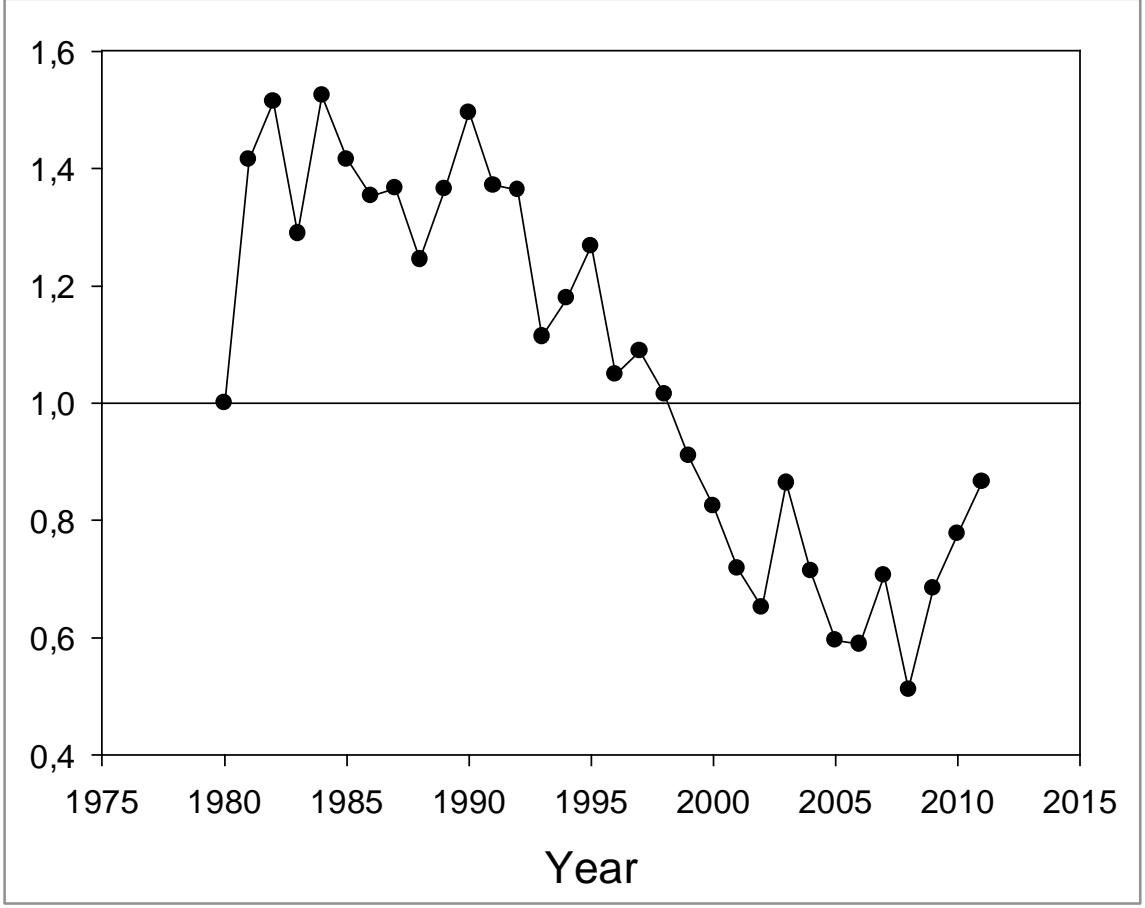

The annual indices for wintering Common Scoter in Norway is highly variable, and there is no significant trend for the period 1980-2011 (Table 4, Fig. 4).

Table 4: National trends for wintering Common scoter in Norway

\begin{tabular}{lrrrrr} 
Area & Period & Number of years & Annual change (\%) & Trend & P \\
National & $1980-2011$ & 32 & -0.04 & $0(-)$ & 0.579 \\
& $2002-2011$ & 10 & 4.36 & $0(+)$ & 0.249 \\
\hline
\end{tabular}

The table lists time period for the counts, number of years with counts within the time period, annual population changes (\%), trend (+/0/-) and the level of significance for the estimated trend calculated using Monte Carlo simulations. 
Fig. 4: National trend for wintering Common Scoter in Norway

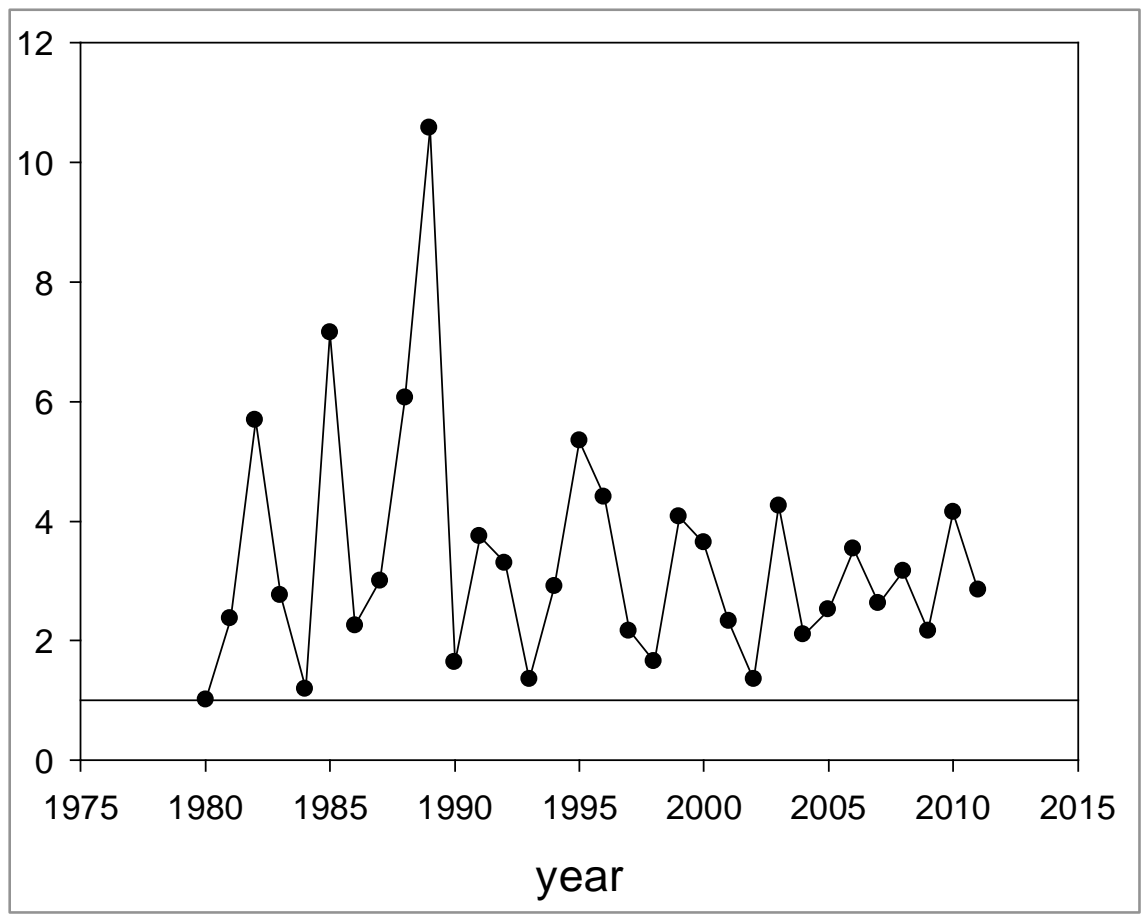

There are very small numbers of Greater Scaup wintering in Norway. The national monitoring only shows a negative, long-term trend for one of the monitored areas (Trondheimsfjorden), but even here wintering numbers are very low.

Baltic Eiders are assumed to winter along the Skagerrak coast. However the annual variation in the proportion of Baltic and "Norwegian" birds in the wintering populations is unknown. For the Common Eider the wintering population in the Skagerrak area has increased significantly, in contrast to a general population decrease along most of the rest of the Norwegian coast. The increase in the wintering population of Eiders is not supported by a concurrent increase in the breeding population so it is assumed that an increasing number of Baltic birds are wintering in Norway. The reason for this increase is unknown, but might be related to both altered food conditions in Danish waters and a general range extension caused by warmer climate (cf. Lehikoinen et al. 2013).

The breeding areas of the wintering populations of Long-tailed Ducks, Common Scoters and Velvet Scoters along the Norwegian coast are unknown. Wintering numbers are assumed to be much higher than the Norwegian breeding populations so it cannot be ruled out that birds from Baltic (or Siberian) breeding grounds winter along the Norwegian coast. The long-term (1980-2011) trends for Long-tailed Ducks are neg- 
ative in all wintering areas from Rogaland in south to Lofoten (Vestvågøy) in the north, mirroring the negative trend observed for Baltic wintering birds.

Wintering numbers of Common Scoter are highly variable but there are a general positive long-term (1980-2011) trend for Vest-Agder (Skagerrak coast) and the northernmost wintering areas (Troms and Finnmark), whereas the wintering population has declined in the Salten area south of Bodø.

Wintering numbers of Velvet Scoters declined in all areas along the coast from Central Norway (Trondheimsfjorden) to Lofoten (Vestvågøy), whereas an increased number was observed in Vest-Agder (Skagerrak coast).

\subsection{Conclusions}

The short conclusion on the validity of the trends in wintering birds in the Baltic Sea may include a suggestion to treat the magnitude of the decreases with caution. This is particularly the case with large-scale inventory events and the categorical assessment of direct comparisons. However, the main conclusion is that the best available evidence suggests that the declining trends as such need not be questioned. Norwegian data also strongly indicates declines in Long-tailed Ducks and Common Eiders, while there are no clear patterns for Velvet and Common Scoters (and Greater Scaup). The trends in particular for Common Eider and Longtailed Ducks suggest that the decrease is true for a larger region than the Baltic/Wadden Sea flyway, and perhaps suggesting that the driver(s) of the decline may be more general and not only specific to the Baltic.

We need to be aware, that our ability to monitor the wintering populations is currently limited and needs considerable improvement.

A separate short discussion on Icelandic Common Eiders will be given in connection with trends in breeding birds. 


\section{Breeding populations of the focal species}

\subsection{Short presentation on numbers and trends in all countries}

This section gives an overview of the current estimates of breeding pair number of the focal species, as well as an indication based on national monitoring schemes on the recent trend for each species. All estimates of breeding numbers and trends are taken from sources which are as up to date as possible. The table also indicates the national IUCN classification of the species.

\subsubsection{The breeding population of the focal species in Finland}

The Finnish breeding populations of Greater Scaup, Long-tailed Ducks and Common Scooters are small, the Greater Scaup has a coastal population which is in the range of just a bit more than 100 pair. In Table (5) trends given in boldface indicate trends obtained from the national monitoring scheme according to a standard classification derived from TRIM-analysis (see Hario \& Rintala 2014, Pannekock \& van Strien 1998). A brief discussion on the adequacy of the monitoring will be given below.

Table 5. Estimates on breeding population size of the focal species in Finland

\begin{tabular}{|c|c|c|c|}
\hline $\begin{array}{l}\text { Species } \\
\text { (IUCN class, national) }\end{array}$ & $\begin{array}{r}\text { Breeding population } \\
\text { estimate }\end{array}$ & $\begin{array}{l}\text { Trend (Italic = coastal } \\
\text { 1986-2013) }\end{array}$ & $\begin{array}{l}\text { Distribution and breeding } \\
\text { habitat* }\end{array}$ \\
\hline Greater Scaup (EN) & 400-600 (coastal 140) & Moderate decline & Northern inland, coastal, \\
\hline Common Eider (NT) & 100,000 & Moderate decline & Coastal \\
\hline Long-tailed Duck (LC) & $1,500-2,000$ & Moderate decline & Northern inland \\
\hline Common Scoter (LC) & $1,000-2,000$ & Stable & Northern inland \\
\hline Velvet Scoter (NT) & $52,000(+1,000$ inland $)$ & Moderate decline (coastal) & Coastal,northern inland \\
\hline
\end{tabular}

The estimates are based mainly on data from the Finnish Atlas (2006-2010) or Hario \& Rintala (2014, in press, up to 2013) concerning coastal populations, supplemented by data from Saurola et al. 2013). Trend indications in boldface follow Hario \& Rintala (2014) and are based on TRIManalyses. Other trend indication according to Valkama et al. (2011). * The habitat indicated first is the more important. 
The Finnish national monitoring system for birds breeding in the archipelago (32 species) is based on cenuses done on 45 different sites (groups of islands) covering the entire length of the coast. The scheme has been active for 65 years, and maintained by voluntary workers. All areas are not visited each year, and the yearly number of islands covered is $1,600-2,000$. The strength of the system is (1) the long-term operation, (2) censuses based on nest-counts for many species (not based on pair or male counts) and (3) comparably large sample sizes for common birds, so that the annual average numbers of for instance Common Eider nests included in the censuses is more than 11,000 . The weakness of the system is largely a question of continuity based on problems in recruiting new census takers, a bias towards protected sites with traditionally large numbers of birds, a rigidness in spatial coverage which does not take into account possible re-location of birds and the lack of census sites on the Åland Islands. On the Åland Islands, censuses are obtained from specific reference sites on the number of pairs of Common Eiders and Velvet Scoters, but these are not reported or coordinated in a national context, which also is a major shortcoming.

For inland breeding populations of the focal species, there is currently no specific scheme for monitoring, which may be considered a major weakness.

\subsubsection{Conclusions on a general level}

Based on the population trends of birds breeding on the coast, Greater Scaup is clearly in danger of disappearing from the coast, Common Eiders are still declining (see also below) as are Velvet Scoters, all trends are significant. For inland populations of Long-tailed duck, Common Scoter and Greater Scaup no alarming changes are known (populations are considered to be stable), but these are not monitored in any detail.

\subsubsection{The breeding populations of the focal species in Sweden}

The national monitoring of the focal species in Sweden is mainly based on the scheme Svensk fageltaxering (SFT). A recent evaluation (Naturvårdsverket 2013) on the reliability of the trend estimates in SFT considers that data is (1) satisfactory for inland populations of Long-tailed Duck, Velvet- and Common Scoter, while (2) trend data for all coastal species are deemed unsatisfactory. SFT operates two different census schemes (fritt valbara punktrutter (point census routes not pre- 
determined, FVP) and standardrutter (standard point-count routes, SR) both of which yield data for national trends (Table 6). Common Eider trends are significantly negative, other trends are listed in Table (6).

\begin{tabular}{|c|c|c|c|c|}
\hline $\begin{array}{l}\text { Species (IUCN } \\
\text { class, national) }\end{array}$ & $\begin{array}{l}\text { Breeding popula- } \\
\text { tion estimate }\end{array}$ & $\begin{array}{l}\text { Trend } \\
\text { (fritt valbara punk- } \\
\text { trutter FVP 1975- } \\
\text { 2013, standardrutter } \\
\text { SR 1998-) }\end{array}$ & Distribution * & $\begin{array}{l}\text { Additional popula- } \\
\text { tion trend indica- } \\
\text { tion, } 30 \text { years up to } \\
2010^{*}\end{array}$ \\
\hline $\begin{array}{l}\text { Greater Scaup } \\
\text { (VU) }\end{array}$ & 1,400 & No data, no data & $\begin{array}{l}\text { Northern inland, } \\
\text { coastal }\end{array}$ & $\begin{array}{l}\text { Probably stable, } \\
\text { decreased on the } \\
\text { coast }\end{array}$ \\
\hline Eider (NT) & 150,000 & $\begin{array}{l}\text { Significant decline, } \\
\text { no significant trend }\end{array}$ & Coastal & $\begin{array}{l}\text { Recent marked } \\
\text { decrease since the } \\
\text { 1990s }\end{array}$ \\
\hline $\begin{array}{l}\text { Long-tailed } \\
\text { Duck (E) }\end{array}$ & 1,300 & $\begin{array}{l}\text { No data, no signifi- } \\
\text { cant trend }\end{array}$ & Northern inland & Probably increased \\
\hline $\begin{array}{l}\text { Common } \\
\text { Scooter (LC) }\end{array}$ & 6,100 & $\begin{array}{l}\text { No data, no signifi- } \\
\text { cant trend }\end{array}$ & Northern inland & Marked increase \\
\hline $\begin{array}{l}\text { Velvet Scoter } \\
\text { (NT) }\end{array}$ & 10,000 & $\begin{array}{l}\text { No data, no signifi- } \\
\text { cant trend }\end{array}$ & $\begin{array}{l}\text { Coastal, northern } \\
\text { inland }\end{array}$ & $\begin{array}{l}\text { Decreasing, both } \\
\text { habitats }\end{array}$ \\
\hline
\end{tabular}

Estimates are mainly according to Ottoson, U. et al. 2012: Fåglarna i Sverige - antal och förekomst. SOF, Halmstad. The trends are according to the national monitoring system (fritt valbara punktrutter 1975-2013, and standardrutter 1998-; http://www.zoo.ekol.lu.se/birdmonitoring/index.html), the additional trends according to Ottoson et al. (2012). * The habitat indicated first is the more important.

\subsubsection{General conclusions}

Clearly, the trend for the coastal population of the Common Eider is still significantly negative. Coastal populations of Greater Scaup are likely decreasing, as are Velvet Scoters. Both Long-tailed Ducks and Common Scoters are seen as having likely increasing trends in inland breeding areas. Based on the evaluation done by Naturvårdsverket (2013), the Swedish national monitoring system needs revision especially for the coastal populations of the focal species. 


\subsubsection{The Danish breeding population of the Common Eider}

For Denmark, only data on Common Eider is included. The Danish Common Eiders are censused mainly based on nest counts at most known colonies.

Table 7. Population estimate for breeding Danish eider ducks

\begin{tabular}{llll}
$\begin{array}{l}\text { Species (IUCN class, } \\
\text { national) }\end{array}$ & $\begin{array}{l}\text { Breeding population } \\
\text { estimate }\end{array}$ & $\begin{array}{l}\text { Trend } \\
\text { National colony monitoring } \\
10 \mathrm{yr} \text { interval 1990-2010 }\end{array}$ & Distribution \\
\hline Eider (LC) & 25,000 & Stable & Coastal \\
\hline
\end{tabular}

Virtually all Danish colonies (>220 sites) are surveyed every 10th year (Christensen \& Bregnballe 2011).

\subsubsection{General conclusion}

The breeding population of the Common Eider in Denmark has remained stable since 1990.

\subsubsection{The Norwegian breeding population of Common Eider}

Generally the long term trend are stable to positive for southeast Norway (Oslofjord area), and along the rest of the Skagerrak coast, decreasing (stable in some areas) in the area from the southwest coast to Finnmark. Short term trends (last ten year period) show increasing breeding populations in the Oslofiord and decreasing or stable breeding populations along the rest of the coast (Figs. 5 and 6, the Norwegian monitoring programme for breeding seabirds, S.-H. Lorentsen pers.comm). 
Fig. 5: The population development (males in breeding areas) of Common Eider along the Skagerrak coast, in Hordaland, Møre and Romsdal, Trondheimsfjorden and Vikna shown as percent of the mean for all years

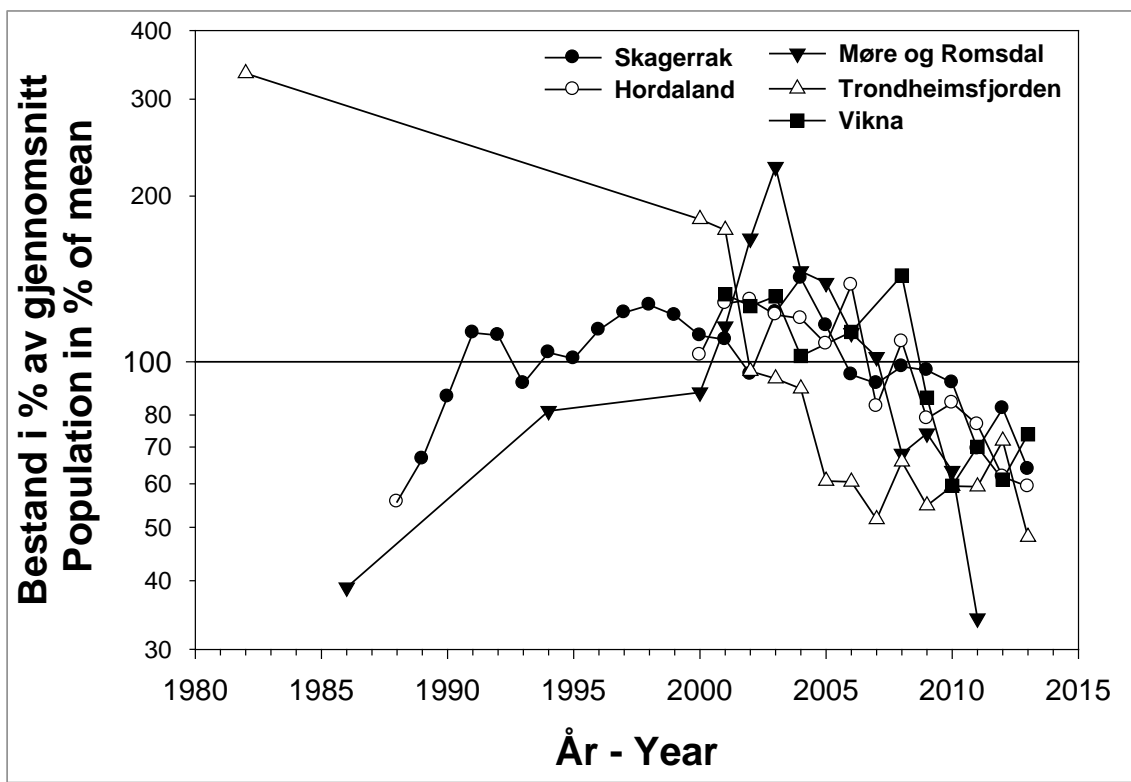

Note that the $y$-axis is logarithmic. The mean is defined as 100 such that 200 represents a population twice the mean, 300 a population three times the mean, 50 half of the mean etc.

Fig. 6: The population development (males in breeding areas) of Common Eider in three areas at the Helgeland coast, Røst, Troms and Varangerfjorden shown as percent of the mean for all years

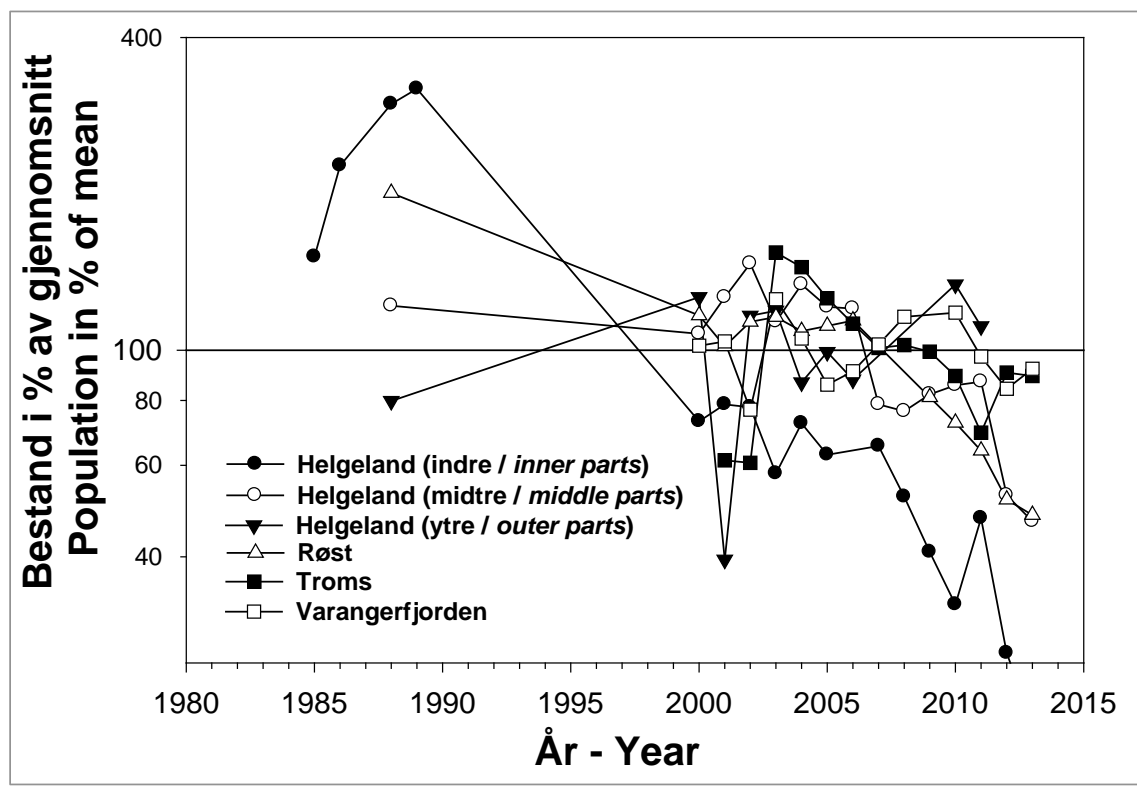

See figure above for a more detailed explanation. 
Norwegian Common Eiders breeding north of Central Norway are assumed to be sedentary, whereas birds along the Skagerrak coast may migrate to Danish (and Swedish) waters in winter.

The Norwegian population monitoring system for breeding Common Eiders has quite good temporal and spatial resolution and is assumed to be representative for the development of the breeding populations. There is, however, a lack of monitoring of other demographic parameters (adult survival, reproductive success), that might help explaining the cause of the observed changes.

There is no monitoring of the breeding populations of Long-tailed Duck, Common- and Velvet Scoters in Norway.

\subsubsection{General conclusion}

Coastal populations of Common Eiders in Norway are decreasing on a general level from the south-west along the coast to the north, while they are increasing in the south-east. Population estimates for breeding population of eiders in Norway (190,000 national total updated in 2005, source (http://www.seapop.no/no/population-sizes/populations-nesting/ results/) have very recently been updated, and show a general decrease of most populations of Common Eiders.

\subsubsection{The breeding population of Common Eider on Iceland}

Based mainly on a recent paper by Jónsson et al. (2013), which is the best available estimate on a national level, the Icelandic population of Common Eiders (total population 300,000 pairs), has not, at least, decreased dramatically since the 1990s. The trends analyzed are, however, based on data from semi-domesticated birds breeding on islands where down is harvested, and the birds are protected from predators. Data on other focal species are unavailable except for populations breeding on Lake Myvátn.

\subsubsection{General conclusion}

There is probably not a national decreasing trend in the Common Eider on Iceland, even though some colonies do show declines in recent years (Jónsson et al. 2013). 


\subsection{Overall conclusions}

Breeding populations of the focal species in Sweden and Finland show a severe decrease in Greater Scaup and Common Eider and a decrease in the Velvet Scoter, when data from coastal populations are considered. Inland populations of Long-tailed Ducks, Greater Scaup and Common Scoter do not seem to be deceasing, but inland populations of Velvet Scoters decrease in Sweden. Populations of Long-tailed Ducks, Greater Scaup and Common Scoters are small, in general, in both Finland and Sweden.

The Norwegian breeding population of Common Eiders are decreasing in most parts of the country, whereas Danish Common Eiders have a stable population, as most likely is the case also on Iceland.

The national monitoring schemes are not all adequate for producing high-quality data even on trends, but the general trends seem robust enough for all focal species, raising concern for the coastal populations of the focal species.

The general problem with all current monitoring schemes on a national level is that they do not produce any data on demography (e.g. productivity and adult survival) for the focal species. This means that our ability to react to changes is limited, as we only can react on retrospective trends. Clearly, if we perceive the trends discussed here as relevant, much action is needed towards improving understanding on a short-term basis by including monitoring of demographic parameters, at least in currently identifiable core breeding areas of the focal species. This specially calls for intensifying data gathering on breeding parameters for all focal species, covering the entire breeding range. 



\section{Details on national declines in coastal populations of the focal species in the Baltic Sea, and regional drivers of the trends}

\subsection{Finland}

Both the Finnish and the Swedish national monitoring schemes covering coastal populations of the focal species identify a similar decrease in the Common Eider - the breeding populations in the Baltic Sea have about halved during the last 15 years, a the decline has been rapid especially in the last 10 years (Ekroos et al. 2012a). The trend is still continuing.

In Finland, national monitoring of the small coastal population of Greater Scaup calls for immediate concern, as the population is in risk of disappearing (Hario \& Rintala 2014).

Also the Finnish coastal population of the Velvet Scoter is decreasing.

\subsection{Common Eider}

The coastal population of the Common Eider shows a general decrease, but a regional break-down of the national census results show different pattern along the coast. Generally ,the population in the Gulf of Finland started to decrease already in the mid-1980s, the decrease in the southwestern archipelagoes (the Archipelago Sea) started to decrease some 15 years ago, and the population breeding on the west coast (Bothnian Sea and Bay of Bothnia) does not show a trend, but the population fluctuates from year to year. Both the Gulf of Finland and the west coast are closer to the distributional margin of the population; when these populations where experiencing a historical peak in the 1990s the south-western archipelagoes where estimated to hold about $80 \%$ of the total population, the Gulf of Finland a considerably smaller proportion (10\%) and the west 
coast a smaller share still (Hildén \& Hario 1993). The total population estimate is uncertain, and also influenced by a lack of good information from the Åland Islands. Thus the bulk of the Common Eider population bred in the Archipelago Sea, but the proportion is only indicative.

\subsubsection{Gulf of Finland and the south-western archipelagoes}

In the Gulf of Finland, the trend in breeding Common Eiders turned negative already in the late 1980s (Hario \& Rintala 2009). The population at Söderskär in the Gulf of Finland decreased about 7\% annually in the period 1986-1999, the population halved by 2006. The Söderskär population in the Gulf of Finland was studied in detail for many decades (see Hario \& Rintala 2009), and it is the only population in the central Gulf of Finland from which estimates of vital rates (productivity, mortality) exists.

In the south-western archipelagoes (see Hario \& Rintala 2009) the population trajectory turned negative abruptly after 1997, and the decline was much steeper than in the Gulf of Finland, the population had halved in the period 1997-2004. No data on vital rates exist from this population, but a population at the western entrance of the Gulf of Finland (Hanko, Tvärminne, see Ekroos et al. 2012b) which shows roughly a similar pattern, with a decrease starting in the last years of the 1990s (Kilpi \& Öst 2002), provides data on vital rates.

The recent estimates on the populations (season 2013, Hario \& Rintala 2014, and unpublished personal information from 2014) both in the Gulf of Finland and the south-western archipelagoes indicates a continual decrease in the south-western archipelagoes and slight recovery in the Gulf of Finland. Roughly, if data from the census areas are taken at face value, the population of the Gulf of Finland is now equal to about $50 \%$ of the peak population, but it may be as low as $20 \%$ (30,000 pairs) or less in the south-western archipelago (Kurvinen 2014). Particularly data from the most important census areas (covering 10,000 pairs in the peak period) in the south-western archipelagoes (Kurvinen 2014) show a continual crash, and may indicate that the total population in the Gulf of Finland and the south-western archipelagoes may be less than 40,000 pairs (i.e. about $20 \%$ of the peak population), and the core breeding area in particular has lost the majority of the breeding birds. The total estimate for Finland of 100,000 birds in 2013 suggested by Hario \& Rintala (2014) seems to be an overestimate.

It is worth noting, that the neighboring population to the south of Finland, the breeding Common Eiders in Estonia, have simultaneously crashed. This population had a peak during the second half of the 1990s 
$(9,000-12,000$ pairs) reduced to $2,000-4,000$ pair in $2009-2012$. Likely reasons for the decline is increased integrated predation by mammalian species and sea-eagles, similarly to that on breeding Barnacle Geese (Branta leucopsis) (A.Leito, pers.comm).

It is also worth noting, that the most important areas censused in the south-western archipelagoes are now virtually void of breeding Eiders, but the current monitoring scheme does not make it possible to ascertain if the birds indeed are missing over the entire area, or have relocated, since virtually no background data is available from other possible breeding sites.

The census data on breeding Common Eiders on the Åland Islands (adjacent to the south-western archipelagoes) is not included here, and it is not adequate to verify any trend. However, recent re-censuses of certain areas (A. Halkka pers comm) indicates a severe crash.

The population of the Velvet Scoter is continuing its decrease. Data from the Åland Islands are not included here, the most recent estimates indicate no real trend (Hartman et al. 2013).

\subsubsection{The west coast}

The population of Common Eiders on the west coast is still fluctuating showing no trend. The population of the Greater Scaup is serisouly decreasing, and the Velvet Scoter is decreasing. The reasons for fluctuating numbers of breeding Common Eiders are not known.

\subsubsection{Reasons for the decline in the Gulf of Finland and the south-western archipelagoes}

Hario et al. (2009), and Hario \& Rintala (2006, 2009) have convincingly argued that the decline of the population of Common Eiders on Söderskär, Gulf of Finland, primarily was driven by very low fledging success, while female mortality remained on a low level throughout the period of decline. However, they also argued that productivity was generally depressed all over the core breeding range in the south-western archipelagoes. This general statement has never been corroborated by any data, and is likely not true. Thus, in the Tvärminne population, productivity has been high throughout the decreasing phase (Kilpi et al. unpublished data), but no data still exists from the core area. Likewise, at Tvärminne, there has been no change in the body condition of breeding females known to affect productivity (Jaatinen et al. 2012), nor in the mean clutch size (unpul. data, Öst et al.). 
At Tvärminne Ekroos et al. (2012b) documented high female mortality (about 72\% apparent annual survival) among breeding birds, contrasting with the situation at Söderskär. A re-analysis of the vital rates at Söderskär and at Tvärminne (Öst et al. unpubl.) strongly suggests that the decline at Tvärminne is driven by high mortality, also corroborating that productivity is the main driver of the decline at Söderskär, even though at both sites both productivity (Tvärminne) and mortality (Söderskär) also contribute to the growth rates of the respective populations. At Tvärminne, and also in the south-western archipelagoes in particular, predation rates on breeding females have increased as a consequence of an increased number of both breeding and floating populations of White-tailed Sea Eagles (Haliaeetus albicilla) (Ekroos et al. 2012, Kurvinen 2014), while at Söderskär no eagle predation was present until 2013.

The best evidence available strongly suggests that the decline initially in the Gulf of Finland was driven by low productivity (heavily biased by evidence from Söderskär), while in more western areas predationinduced high female mortality (biased by evidence from Tvärminne) drives the decline. Predation rates on nests are not reported in the national census work, and hence data on these rates are not available on a larger scale.

However, rates on nest predation and dead female numbers on islands can be easily obtained during the counting of nests on the islands, On a qualitative basis, predation rates appear very high during the last decade. Predation on females not only induces higher mortality, but also has secondary effects such as elevated nest predation rates and also elevated rates of predation on broods at sea.

The ultimate cause of low reproductive success in the Söderskär population may not be fully understood (Hollmen 2002), but ducklings were affected by both viral disease lowering their immune defense and making them susceptible to secondary infections, when the final cause of death often is diagnosed as coccidian infection (Hollmen 2002). In the mid1990s populations of the major food items by adult Common Eiders and also larger ducklings, Blue Mussels, where comparably low at Söderskär, higher at Tvärminne, and pronouncedly much higher in the south-western archipelagoes (Westerbom et al. 2002). Since, mussel populations have not changes for the worse in any of these areas (Westerbom 2006, Westerbom, pers.com.). Based on abundance at least, Blue Mussels have not been in short supply in the core area experiencing the most steep decline in Common Eiders, and hence likely not an issue. There is no indication that Blue Mussel quality as food for the birds in any way would have been changing for the worse in the core breeding area of the Common 
Eider in Finland (see Larsson \& Waldeck 2013). In the central part of the Gulf of Finland, on the other hand, Blue Mussel abundance may have played a part initially in the low production of young.

\subsubsection{Why did the Finnish Common Eider population crash?}

The most likely explanation for the crash of the breeding Common Eider population in the south-western Archipelagoes (i.e. the core area of the species distribution) is elevated predation on adult breeding females by primarily White-tailed Sea Eagles, and also by introduced American Mink (Mustela vison) and Raccoon Dog (Nyctereutes procyonoides). It seems also very likely that, as the effect of predation is currently spreading also to the Gulf of Finland, the situation there will change. Further, as the core areas of the Common Eider in the barren, outer archipelagoes in the south-western archipelago have become depopulated, predation effect may escalate elsewhere. It is also unknown if Common Eiders are able to react by relocation, even if current evidence for high breeding philopatry is strong (Lehikoinen et al. 2011). It seems equally plausible that the initial decrease in the Gulf of Finland was caused by low reproductive success, perhaps due to high duckling mortality because of disease (Hollmén 2002).

The fact that the adult population of Common Eiders in Finland is increasingly male-biased (Lehikoinen et al. 2008, and unpublished data, currently a proportion of nearly $70 \%$ males), strongly suggests that mortality rates of females have changed, likely due to an increase in predation rates during breeding. Pertinent to this point, is that the sex-ratio of Eiders tied to breeding colonies in Denmark seem to be at parity (Christensen \& Bregnballe 2011).

Historically, the Finnish coastal population reached an all-time low in the early 1900s (Hildén \& Hario 1993). The reduction in numbers at that time was likely due to overexploitance of the Eiders as a resource for local people, adults through hunting, nests by egging and downcollecting and overall poor legislation. The establishment of sanctuaries for breeding ducks in the archipelagoes starting in the 1930s set the Common Eider on a rising trend. As far as documentation, we do not know what the pre-man population size may have been, and we do not know how this population interacted with the predators affecting it. 


\subsubsection{Other species on the coast}

Data are too scanty to allow any conclusions on the reasons for decline of the Greater Scaup and the Velvet Scoter breeding on the coast.

\subsubsection{Summary on drivers}

The decline of the Common Eider breeding population is most likely driven by increased predation on breeding females, and to a lesser extent by low reproductive success. Drivers for the declines in Greater Scaup are unknown, and data on drivers of the Velvet Scoter populations on the coast are not verified.

\subsection{Common Eiders on the Swedish coast}

On a national scale, the Swedish population of the Common Eider shows a similar development as the Finnish (Ekroos et al. 2012). Thus the population has halved from 2000 to 2009, and as in Finland, there is spatial variation in the development of the population.

On the Swedish west coast, populations were stable over a long period of time, but have recently experienced a fast decline (Naturvårdsverket 2013). In the Baltic Sea the trend is overall negative (Green \& Lindström 2014). The core area for the Common Eider in Sweden is the Stockholm archipelago, which was estimated to hold as many pairs as 100,000 (75\% of the estimated current total, (Ottoson et al. 2012, Sveriges Ornitologiska Förening 2009). In this core-are, large scale inventories done in 1971-1976 and 2000 show how the Common Eider increased and expanded, but the effects of the recent decline are still unclear in this particularly well documented area. Regional inventories document significant decreases in very recent years (70\% decrease 20012013; http://www.lansstyrelsen.se/stockholm/SiteCollectionDocuments/ Sv/publikationer/2013/Kustfagel-Norrtalje-2013-FAKTA-KLAR.pdf), with particular decreases in the most barren, outer archipelago zones (see also Skärgårdsstiftelsen 2014). More precise data from the core area would be needed, but the trend is very much in line with the national trend.

Off the island of Gotland, eiders have recently undergone a major decline (K. Larsson, pers comm) but see also Larsson et al. 2014). Initially, Larsson et al. (2014) reported a rapid decline of up to $70 \%$ from 2007 to 2008 , followed by a recovery. The recovery has since again transformed into a very rapid decline, so that in 2014 only $20 \%$ of the 2007 population remained (K. Larsson, pers. comm). 
Thus, it is reasonably clear that the breeding population of Common Eiders in the Swedish core breeding area, and also elsewhere has declined and is still declining.

It may be relevant to consider that censuses of breeding Eiders in Sweden are partly based on counts of male birds. As the sex-ratio skew observed in Finland seems to be a more general phenomenon, it may well affect the Swedish trends, but this is not known, see however, Skärgårdsstiftelsen (2014). If the effect is present, the decline in Sweden may be faster than indicated by the trends which include male counts only.

\subsubsection{Why did the Swedish population of Common Eiders decline?}

There is simply not enough systematic data on breeding, production of young or female survival from Sweden for the Common Eider to corroborate what is driving the decline. Some drivers may be the same as in Finland, as the core areas for breeding of Common Eiders have many similarities with those in Finland. However, there are some dissimilarities as well. Larsson et al. (2014) documented a rapid decline off the island of Gotland in 2007/2008 which was attributed to effects on Blue Mussels mediated via heavy blooms of a potentially harmful algae, Prymnesium polylepis. While there was a partial recovery of the population after this episodic event, the data gathered revealed that the clutch size of Eider Ducks at Gotland was reduced compared with the Finnish population (Tvärminne) used in the study, and at least qualitative observations confirmed a very low reproductive output. The population subsequently crashed, and recent observations confirm that one proximate reason at Gotland is predation by White-tailed Sea Eagles (K. Larsson, pers. comm). Predation may however, not explain the reduction in clutch size, which may have prevailed for a number of years.

Both observations on the immediate effect of an algae on breeding propensity, and the observation on a depressed clutch size may indicate that Eiders on Gotland are also affected by a different causative agent, which in turn may be connected to the food chain. As summarized by Ottvall (2012) populations of Blue Mussels off Gotland may have been stable, while some data indicate that they have decreased in parts of the Stockholm archipelago. While it seem reasonably clear that mussel quality may vary between years due to effects on mussel condition (Larsson \& Waldeck 2013) it is not clear that mussels per se would have a direct effect on breeding Eiders. On a qualitative basis, Blue Mussels off the Finnish coast are, however, more abundant than off Gotland (K. Larsson, 
pers. comm). There are, however, no direct evidence for changes in plankton webs which would have reduced the quality of Blue Mussels off Gotland in phase with the decline in the Eider population, even though it is clear that plankton communities in general at least in the northern parts of the Baltic Sea have changed (Suikkanen et al. 2013). The effects of these long-term changes on Blue Mussels are unknown.

Further, Balk et al. (2009) have suggested that the decline in the Common Eider is due to a general deficiency in thiamine (B1-vitamine). Thiamine is produced by phytoplankton and enters the food chain for eiders via filtering Blue Mussels, and could thus be related to changes in plankton community structure. In birds, including Eiders, thiamine deficiency produces an easily recognizable syndrome leading to death of the affected birds (or possible non-lethal effect affecting breeding), and is linked to so called mass mortality episodes prevalent mainly off the Swedish east coast south of the core breeding area of the Common Eider. In the studies by Balk et al. (2009) samples from the core breeding area in Sweden were included, and concentrations of thiamine in yolk of Eider eggs were significantly lower than concentrations measured from samples from Iceland. Yolks from the Tvärminne Eider populations were included in the sample from the Baltic.

The effect on the decline is far from clear (see also Ottvall 2012). Balk et al. (2009) refer to a productivity over several years of 1 duckling / 100 adult females, but this is far from conclusive data. At Tvärminne, which also would be affected, productivity has been much higher on the average throughout the decline (> 50 ducklings / 100 females, unpubl. data).

Die-offs fulfilling the thiamine deficiency syndrome have not been encountered on the Finnish coast. Recent studies by Sylvander et al. (2013) suggest that regime shifts in phytoplankton community composition through large-scale environmental changes has the potential to alter the thiamine availability for higher trophic levels. A decreased access to this essential vitamin may have serious consequences for aquatic food webs. If such changes have occurred already is unclear.

There may also be other explanations, both currently viable and possible, future factors affecting the Common Eider via the food web. The array of such factors is diverse, and may include a number of agents (e.g. toxins, microplastics).

Apart from some effects through heavy metals (see Hollmén 2002), such agents are largely unknown. 


\subsubsection{Other breeding species}

For coastal populations of Greater Scaup and the Velvet Scoter, data are too scanty to allow for any conclusions.

\subsubsection{General conclusion}

Apart from an effect of predation which is poorly documented, there is not much coherent evidence for a causative agent in the decline of the Common Eider in Sweden. Perhaps the best indication of agents other than in Finland come from Gotland, were clutch size reduction suggests that the environment would be different with respect to feeding conditions for females. If this difference is due to Blue Mussels and the quality of these mediated via changes in the planktonic community linked to thiamine is an open question (see also Sylvander et al. 2013). The parallels between the Swedish core area in the Baltic Sea and the Finnish core area suggest that at least the predation regime on adult Eiders has changed in a similar fashion, but conclusive data are lacking.

\subsubsection{Summary on drivers of the decline}

For Common Eiders, there appears to be a need to verify drivers more exactly in the southern part of the Baltic coast, as these populations show a decrease in clutch size. This reduction may indicate that the general circumstances for breeding have deteriorated due to unknown reasons related to the feeding circumstances of the females. In other parts of the Baltic range, predation needs to be considered as a candidate for driving the decline. For other parts of the range, i.e. the Swedish west coast, drivers remain unknown, as they also remain unknown for other species breeding along the Baltic coast.

\subsection{Denmark}

The Danish population of Common Eiders has been stable for decades (Christensen \& Bregnballe 2011). Perhaps the only site with a negative trend with profound interest for the Baltic Sea case is the slight negative development on Ertholmene (Christiansö), near Bornholm south of Gotland. This population peaked in 1992 (3,000 pairs), after which it declined to 1,060 pairs in 2008 (Laursen \& Möller 2014), after which it recovered again to 1,850 pairs in 2010. Incidentally, 2008 was the year when these Eiders likely were affected by the Prymnesium polylepis- 
event (Larsson et al. 2014). However, in 2014 the population had already reached 2,075 pairs after a rapid recovery (http://www.chnf.dk/ aktuelt/edf14/edfugl14.php).

Laursen \& Möller (2014) ascribe the decline at Christiansö to a reduction in nutrients in the Wadden Sea (and off the breeding island in the Baltic) leading to a reduction in Blue Mussels. They further state that the dynamics at Christiansö are typical of other populations in the Baltic/Wadden Sea flyway, and suggest that food supply due to dwindling mussel stocks due to a general reduction in nutrient level in the sea are the causative agents driving the populations. However, given that the population since recovered fast, the conclusions may not be very robust, and the Ertholmene (Christansö) population shows an aberrant development compared with other populations in the Baltic/Wadden Sea flyway area. It may be worth mentioning that the Christiansö population breeds in a protected environment with regards to predators.

\subsubsection{Drivers of the trend}

The stable trend in Denmark is encouraging, and the differences in the circumstances for breeding compared with the Baltic Eiders needs to be clarified. The suggestion made by Laursen \& Möller (2014) that the Baltic Eider colony at Christiansö is representative of entire Baltic breeding population as to the trend seems unlikely, especially since the colony has grown rapidly in recent years.

\subsection{Norwegian and Icelandic Common Eiders}

In the few monitored colonies on Iceland from which long-term data exist, the number of Eiders have been recently suggested to fluctuate as a response over the long run to climatic factors (Jónsson et al. 2014). The driver of the largely negative trend in the breeding (and wintering) Norwegian Eiders is largely unknown. Many of the factors discussed for the Baltic Sea populations (increased predation by White-tailed Sea Eagles, Mink and Otter, Lutra lutra), changes in Blue Mussel availability / and or Blue Mussel quality could also be valid for the Norwegian population. 


\title{
5. Working for the future
}

\author{
5.1 Answers to basic questions: are data from \\ current monitoring sufficient to verify trends?
}

Trend verification ideally comes from data tailored for the purpose of tracking changes in populations over time. The tailored solutions over the nations involved in the trends analyzed here are the national monitoring programs on both breeding and wintering birds, some of which are also multinational ventures such as the study by Skov et al. (2011).

The national monitoring data verify some significant negative trends for breeding birds of the focal species, i.e. declines in:

- Greater Scaup - (coastal population, both in Finland and Sweden).

- Common Eider - (Finland, Sweden and Norway).

- Velvet Scoter - (coastal populations, in Finland and in Sweden also inland populations).

Clearly, there is no need to question these trends as such without seriously questioning the way data is collected in each of the countries.

For other than these negative trends, some trends are deemed as adequately verified on a national level. These include (Sweden) inland breeding populations of Greater Scaup, probably stable), Long-tailed Duck (likely increase) and Common Scoter (marked increase), and the Common Eider population in Denmark.

The monitoring effort on inland populations of Greater Scaup, Longtailed Duck and Common and Velvet Scoter in Finland is not adequate for trend analysis. In Norway, only Common Eiders are included in the monitoring of breeding populations, which is the case on Iceland as well, apart from local monitoring efforts.

The study by Skov et al. (2011), supplemented by other observations as well identifies negative trends for wintering populations of both Long-tailed Ducks and Common Scoters. It is important that not only the study by Skov et al. (2011) but also other recent data from the International Waterfowl Count (IWC) highlights the case of the Longtailed Duck, and has resulted in the first step towards an AEWA International single species action plan for globally threatened Long-tailed 
Ducks (http://www.unep-aewa.org/en/news/first-steps-taken-towardsaewa-international-single-species-action-plan-globally-threatened).

\subsection{How can we be more effective in establishing trends?}

Clearly, some national monitoring is not totally adequate for detecting trends, and often far from effective in the sense that data on vital rates are not included in any monitoring scheme on a national level. Improving the monitoring schemes does not fall within the scope of this report, but it would be beneficial to evaluate the national efforts and also look for ways to coordinate monitoring work on a larger scale.

\subsection{The state of knowledge about the drivers of the negative trends}

The current population decline in the focal species of mussel eating seaducks present in the Baltic Sea during (1) winter or (2) all the year highlight the complexities for understanding drivers of change. Perhaps the first obvious lesson to be learned here is the case of the birds breeding and wintering within the Baltic Sea, Common Eiders, Velvet Scoter and Greater Scaup. Greater Scaup breeding populations, although small, clearly are in peril in both Sweden and Finland, and Common Eider populations in both countries are decreasing. For the two first species we know close to nothing about the drivers of the decline - are the birds primarily facing a threat on the breeding ground or on the wintering grounds?

The Common Eider on the other hand, is a species we know comparably much about, yet we lack knowledge on basic parameters affecting demography and population dynamics, such as e.g. reproductive performance, adult survival, natality and longevity.

In all three cases the first measure would be to gather better information.

Starting from the breeding grounds, much effort has been put into establishing where the birds breed, and we clearly have enough knowledge to be able to identify the core areas for breeding. Yet, in the basic national monitoring of the breeding numbers, we make no attempt to focus on these areas as a first step towards a better understanding. We should change our monitoring strategy to focus more on the core 
breeding areas of the species we are concerned with, especially if we want data on breeding performance.

At the same time, it could be argued that data from more sub-optimal breeding areas may show negative development prior to the core areas, and monitoring should perhaps at its best be based on a stratified random sampling regime.

In the case of the Common Eider, it seems that one plausible explanation for a large-scale decline driver is clearly a changing predation regime affecting breeding birds heavily. Taking on a short-term way of looking at that explanation, we both need to address the potential problem, and we further need to react to it in a meaningful way. This would mean that a proximate reason for the decline would be the first target in management. In a similar way, possible changes on the core breeding area should be sought for also for the other species. As this report has made it reasonably clear, that we do have trends which are reliable based on previous efforts, we should trust the significance of the trends, and react. Trend-spotting in the case of long-lived seaducks is in any case a very blunt instrument, since when trends hit significance in a statistical sense, the trajectory of the population development may already be beyond the point when meaningful management becomes virtually impossible.

Thus we should:

- do better monitoring including vital rates at least on sites where most of the breeders reproduce

- try to quantify the impact of very plausible threats and changes on site were the birds breed

- we should do on site management on the breeding grounds when need arises.

If, on the other hand, we have good reason to suspect that the problem for the focal population primarily lies elsewhere than on the breeding grounds, we should locate the effort there. In the case of the Common Eider, if we think the problem lies on the main wintering grounds, we should do research there, most likely on the state of primary food the birds use.

Again, much effort has been put into identifying the main wintering areas of the focal species within the Baltic Sea, but not too much effort has been put into research on the quality of these areas, the resources the birds use, and the changes these resources may have undergone during the identified period of population decline. And clearly, even if 
the focal species does not breed in the focal region- the Baltic Sea - such as with the Long-tailed Duck and the Common Scoter, we may be able to at least pin-point if the main problem connected to the population decline lies at the wintering grounds (for instance some factor causing overt mortality), or if it is indeed on the breeding area (such as monitoring the proportions of young Long-tailed Ducks in the Baltic in winter). Wintering seabirds use a very small fraction of total area of the Baltic Sea in winter, and basically we know the habitats used and the resources the birds need, so we should focus on these. This does not categorically mean that we know over time the preferences of the birds, but new marking techniques could be used for tracking movements, which currently is an under-used approach in the Baltic Sea.

Thus we should:

- focus on habitats and resources used in the core winter areas of each focal species if within the Baltic Sea

- do meaningful ecological studies on interactions on site

- focus on developing monitoring of seabird use of the Baltic Sea so we can track the major wintering areas used over time. These efforts require multi-national cooperation and coordination.

If the causative agent of a population trend cannot be specified as acting primarily on reproductive areas or survival areas, or can be in other ways identified, management of the current population may be impossible. Hypothetically, if a major regime shift in planktonic webs leading to a major shift in availability of thiamine will take place at some point in time, or if it indeed has already happened, the management problem for the current bird populations on the shorter term will become vague. The Baltic Sea is generally a disturbed environment because of eutrophication, and the amendment of the situation is far from reached and the outcome uncertain indeed from the perspective of the mussel eating seaducks. This means that we may be able to do very little for them, and yet we may be able to do rewarding research on a basic level. This basic level, however, does not very well serve a management purpose. Likewise, if we cannot identify and agree on likely proximate causes for population declines and rank, prioritize and tackle them in a management perspective, we may not even need monitoring. 
Thus we should likely:

- focus management oriented research and action on identifiable short- and middle term questions and actions, but

- allow for basic research trying to identify more long-term threats and open questions as well. 



\section{References}

Aarvak, T., Øien, I.J., Krasnov, Y.V., Gavrilo, M.V. and Shavykin, A.A. (2013). The European wintering population of Steller's Eider Polysticta stelleri reassessed. Bird Cons. Int., 23, pp 337-343. http://dx.doi.org/10.1017/S0959270912000251

Balk, L., Hägerroth, P., Åkerman, G., Hanson, M., Tjärnlund, U., Hansson, T., Halgrimsson, G.T., Zebuhr, Y., Broman, D., Mörner, T. \& Sundberg, T. (2009). Wild birds of declining European species are dying from a thiamine deficiency syndrome. - PNAS 106:12011-12006. http://dx.doi.org/10.1073/pnas.0902903106

Bellebaum, J., Kube, J., Schulz, A.,Skov,H., \& Wendeln, H. (2014). Decline of Longtailed Duck Clangula hyemalis numbers in the Pomeranian Bay revealed by two different survey methods Ornis Fennica 91:129-137.

Christensen, T.K. \& Bregnballe T. (2011): Status of the Danish breeding population of Eiders Somateria mollissima 2010. - Dansk. Orn. Foren.Tidskr. 105: 195-205.

Delany, S. \& Scott, D. eds. (2006). Waterbird Population Estimates. 4th Edition. Wetlands International, Wageningen, The Netherlands.

Durinck, J., Skov, H., Jensen, F.P. \& Pihl, S. (1994). Important Marine Aeras for Wintering Birds in the Baltic Sea. - EU DG XI research contract no. 2242/90-09-01. Ornis Consult Report. 110 pp.

Ekroos, J., Fox, A.D., Christensen, T.K., Petersen, I.K., Kilpi, M., Jónsson, J.E., Green, M., Laursen, K., Cervencel, A., de Boer, P., Nilsson, L., Meissner, W., Garthe, S. \& Öst, M. (2012a). Declines amongst breeding Eider Somateria mollissima numbers in the Baltic/Wadden Sea flyway. Ornis Fenn. 89: 81-90.

Ekroos, J,. Öst,M., Karell, P., Jaatinen, K. \& Kilpi, M. (2012b). Philopatric predisposition to predation-induced ecological traps: habitat-dependent mortality of breeding eiders. Oecologia. 170: 979-986. http://dx.doi.org/10.1007/s00442-012-2378-9

Green, M. \& Lindström, Å. (2014). Övervakning av fåglarnas populationsutveckling. Årsrapport för 2013. Rapport, Biologiska institutionen, Lunds Universitet. 78 pp.

Hario, M. \& Rintala, J. (2006). Fledging production and population trends in Finnish common eiders (Somateria mollissima mollissima) - evidence for density dependence. Canadian Journal of Zoology 84:1038-1046. http://dx.doi.org/10.1139/ Z06-077

Hario, M. \& Rintala, J. (2009). Age of first breeding in the Common Eider (Somateria m. mollissima) population in the northern Baltic Sea. Ornis Fennica 86:81-88.

Hario, M. \& Rintala, J. (2014). Saaristolinnuston kehitys Suomen rannikoilla 19862013 (Summary: Population trends of archipelago birds along Finnish coasts during 1986-2013). Linnut Vuosikirja 2013: 46-53.

Hario, M., Mazerolle, M.J. \& Saurola, P. (2009). Survival of female common eiders Somateria m. mollissima in a declining population of the northern Baltic Sea. Oecologia159:747-756. http://dx.doi.org/10.1007/s00442-008-1265-x

Hartman, M., Kölzsch, A., Larsson, K., Nordberg, M. \& Höglund, J. (2013). Trends and population dynamics of a Velvet Scoter (Melanitta fusca) population: influence of density dependence and winter climate. J. Ornithol 154:837-847.

http://dx.doi.org/10.1007/s10336-013-0950-7 
HELCOM (2013). HELCOM Red List of Baltic Sea species in danger of becoming extint. Balt. Sea Environ. Proc. No. 140.

Hildén, O. \& Hario, M. (1993). Muuttuva saaristolinnusto. Forssa.

Hollmén, T. (2002). Biomarkers of health and disease in Common Eiders (Somateria mollissima) in Finland. PhD-thesis, Dept. of Basic Veterinary Medicine, Univ. Helsinki. 57 p. +6 app.

Jaatinen, K., Öst, M. \& Lehikoinen, A. (2011). Adult predation risk drives shifts in parental care strategies: a long-term stud. J. Anim. Ecol. 80:49-56. http://dx.doi.org/10.1111/j.1365-2656.2010.01757.x

Jónsson, J.E, Gardarsson, A., Gill, J., Pétursdóttir, U. K., Petersen, A. \& Gunnarsson, T.G. (2013). Relationships between long-term demography and weatehr in a sub-arctic population of Common Eider. PLOS ONE 8: e67093. http://dx.doi.org/ 10.1371/journal.pone.0067093

Kilpi, M. \& Öst, M. (2002). The effect of white-tailed sea eagle predation on breeding eider females off Tvärminne, Western Gulf of Finland. Suomen Riista 48:27-33 (in Finnish with English summary).

Kurvinen, L. (2014). Linking habitat and environmental variables to changes in abundance of the Common Eider (Somateria mollissima) in the Archipelago Sea (SW Finland). MSc-thesis, Dept. of Biology, Univ. Turku, $68 \mathrm{p}$.

Larsson, K., Hajdu, S., Kilpi, M., Larsson, R., Leito, A. \& Lyngs, P. (2014). Effects of an extensive Prymnesium polylepis bloom on breeding eiders in the Baltic Sea. J. Sea. Res 88:21-28. http://dx.doi.org/10.1016/j.seares.2013.12.017

Laursen K., Møller A.P. (2014). Long-Term Changes in Nutrients and Mussel Stocks Are Related to Numbers of Breeding Eiders Somateria mollissima at a Large Baltic Colony. PLoS ONE 9(4): e95851. http://dx.doi.org/10.1371/journal.pone.0095851

Lehikoinen, A., Christensen, T. K., Öst, M., Kilpi, M., Saurola, P. \& Vattulainen, A. (2008). Large-scale chnage in the sex ratio of a declining Eider population. Wildl. Biol. 14:288-301. http://dx.doi.org/10.2981/ 0909-6396(2008)14[288:LCITSR]2.0.C0;2

Lehikoinen, A., Jaatinen, K., Vähätalo, A. V., Clausen, P., Crowe, O., Deceuninck, Hearn, R., Holt, C. A., Hornman, M., Keller, V., Nilsson, L., Langendoen, T., Tománková, I., Wahl, J. \& Fox, A. D. (2013). Rapid climate driven shifts in wintering distributions of three common waterbird species. Global change biology 19: 2071-2081.

http://dx.doi.org/10.1111/gcb.12200

Naturvårdsverket (2013): Övervakning av sjöfåglar. Regeringsuppdrag till Naturvårdsverket RB 2013.

Ottoson, U., Ottvall. R., Elmberg, J., Green, M., Holmqvist, N., Lindström, Å., Nilsson, L., Svensson, M., Svensson, S. \& Tjernberg, M. (2012). Fåglarna i Sverige - antal och förekomst. SOF, Halmstad.

Ottvall, R. (2012). Ejdern och andra musselätande dykänders minskning I Östersjön. Miljöforskningsberedningen, Rapporter, 29 augusti 2012.

Pannekock, J. \& van Strien, A. (1998). Trim 2.0 for Windows (trends \& indices for monitoring data). Statistics Netherlands.

Petersen, I.K. \& Nielsen, R.D. (2011). Abundance and distribution of selected waterbird species in Danish marine areas. Report commissioned by Vattenfall A/S. National Environmental Research Institute, Aarhus University, Denmark. 62 pp.

Saurola, P., Valkama, J. \& Velmala, W. (2013). The Finnish Bird Ringing Atlas. Vol. I. Finnish Museum of Natural History and Ministry of Environment, Helsinki.

Skärgårdsstiftelsen (2014). Levande skärgårdsnatur 2014 - med rapporter från 2013. Skärgårdsstiftelsen i Stockholms län. 
Skov, H., Heinänen, S., Žydelis, R., Bellebaum, J., Bzoma, S., Dagys, M., Durinck, J., Garthe, S., Gennady Grishanov, G., Hario, M., Kieckbusch, J.J., Kube, J. Kuresoo, A., Larsson, K., Luigujoe, L., Meissner, W., Nehls, H.W., Nilsson, L., Petersen, I.K., Roos, M.M., Pihl, S., Sonntag, N., Stock, A. Stipniece A. and Wahl,J. (2011). Waterbird Populations and Pressures in the Baltic Sea. Nordic Council of Ministers, TemaNord 2011:550 ISBN 978-92-893-2249-2.

Suikkanen, S., Pulina, S., Engsström-Öst, J., Lehtiniemi, M., Lehtinen, S. \& Brutemark, A. (2013). Climate chnage and eutrophication induced shifts in northern summer plankton communities. PLOS ONE 8:e66475. http://dx.doi.org/10.1371/ journal.pone.0066475

Sylvander, P., Häubner, N. \& Snoeijs, P. (2013). The thiamine content of phytoplankton cells is affected by abiotic stress and growth rate. Mocrob. Ecol. 65:566-577. http://dx.doi.org/10.1007/s00248-012-0156-1

Valkama,J., Vepsäläinen, V. \& Lehikoinen, A. (2011). Suomen III Lintuatlas. Luonnontieteellinen keskusmuseo ja ympäristöministeriö. http://atlas3.lintuatlas.fi (viitattu [päivämäärä]) ISBN 978-952-10-6918-5.

Waldeck, P. \& Larsson, K. (2013). Effects of winter water temperature on mass loss in Baltic blue mussels: implications for foraging. J. Exp. Marine Biol. 444:24-30. http://dx.doi.org/10.1016/j.jembe.2013.03.007

Westerbom, M., Kilpi, M. \& Mustonen, O. (2002). Blue Mussels, Mytilus edulis, at the ege of the range: population structure, growth and biomass along a salinity gradient in the north-eastern Baltic Sea. Mar. Biol. 140:991-999. http://dx.doi.org/10.1007/s00227-001-0765-6

Westerbom. M. (2006). Population dynamics of blue mussels in a variable environment at the edge of their range. PhD-disseratation, Dept. of Biol. And Eniron. Sciences, Univ. Helsinki.

Wilson, H.M., Flint, P.L., Powell, A.N., Grand, J.B. \& Moran, C.L. (2012). Population ecology of breeding Pacific Common Eiders on the Yuokon-Kuskokwim Delta, Alaska. Wildlife Monographs 182:1-28. http://dx.doi.org/10.1002/wmon.8

Zydelis, R., Lorentsen, S-H., Fox, A.D., Kuresoo, A., Krasnov, Y., Goryyaev, Y., Bustnes, J.O., Hario, M., Nilsson, L. \& Stiepniece, A. (2006). Recent changes in the status of Steller's Eider Polysticta stelleri wintering in Europe: a decline or redistribution? Bird Conserv.Intern. 16:217-236. http://dx.doi.org/10.1017/S0959270906000360 



\section{Sammanfattning}

I rapporten ges en översikt av populationstrender för fem arter dykänder vilka häckar, eller övervintrar, inom Östersjöområdet. En jämförelse med trender observerade i Norge och på Island ingår i rapporten. De arter som ingår är bergand (Aythya marila), ejder (Somateria mollissima), alfågel (Clangula hyemalis), sjöorre (Melanitta nigra) samt svärta (M. fusca). Enligt nya skattningar har alla de här arterna minskat kraftigt i Östersjön, och gemensamt för dem är att de livnär sig på musslor, speciellt blåmussla (Mytilus edulis x M. trossulus).

Verifierade trender för Östersjöområdets kusthäckande arter omfattar snabb och brant minskning i bestånden av bergand, ejder och också svärta både i Sverige och i Finland. Ejderpopulationen i Danmark är stabil. Ytterom Östersjön minskar ejder i Norge, medan den Isländska ejderpopulationen verkar rätt stabil. De kusthäckande populationerna av både bergand och svärta är små, och speciellt berganden verkar löpa risk för att försvinna helt.

Inlandshäckande populationer av bergand, alfågel och sjöorre i både Sverige och Finland ter sig rätt stabila, eller växande, men dessa populationer är små. I Sverige minskar inlandsbeståndet av svärta sannolikt. Ingen nationell uppföljning av andra häckande arter än ejder görs i Norge och på Island.

De minskande antalen övervintrande dykänder i Östersjön, som nyligen rapporterats av Skov mfl. (2011) tyder på nedgångar i storleksordningen $50 \%$ hos alla arter som behandlas i denna rapport mellan tidsperioderna 1988-1993 och 2007-2009. Alfågelns nedgång (65\%) är mest extrem. På det stora hela observeras liknande trender för övervintrande alfågel och ejder på den Norska kusten. Få bergänder övervintrar vid den Norska kusten, och trenderna för både sjöorre och svärta är inte helt uppenbara.

Oberoende av det att det kan vara svårt att i vissa fall tolka det data som använts i rapporten av Skov mfl. (2011), kan generaliteten i trenderna uppskattas som god, och trenderna stöds också av dokumenterad utveckling i numerär hos kusthäckande arter inom Östersjön. Också den trend som observerats hos alfågel stöds av nyare data (Bellebaum mfl. (2014). I rapporten av Skov mfl. (2011) ingår också mycket användbara kartor över den utbredning de olika arterna har i Östersjön vintertid. 
Utbredningskartorna kan användas till att förbättra uppföljning och som stöd om man vill sätta in forskningsinsatser eller skötselåtgärder. Sådana insatser kunde också gälla mer allmänt tillståndet i havet och näringsresurserna för övervintrande fågel. Insatserna borde vara av multinationell, koordinerad karaktär. Dessutom är trenderna hos de arter som rapporten omfattar så klara, att det skulle te sig väl motiverat att gå in för åtgärder som kunde bryta den negativa trenden.

De nationella uppföljningsprogrammen som finns till för att dokumentera trender hos de arter som behandlas i denna rapport, borde ses över. Detta gäller både i inlandsomgivningar och vid kusten. Dock ter det sig rimligt klart, att de uppföljningsprogram som hittills använts, räcker till för att säkerställa nedgången hos speciellt kusthäckande bergand, ejder och svärta. För alla tre arters del finns akuta behov av att åtgärda trenden i Sverige och Finland.

Vad gäller de orsaker som ligger bakom trenderna observerade inom Östersjöns häckande bestånd, kan konstateras, att vi vet nästan ingenting om de orsaker som gör att bergand och svärta minskar. Det data som finns framtaget för ejderns del, tyder på att ökande predation mot häckande fågel i Finland sannolikt är ett allvarligt problem då det gällerpredation orsakad av havsörn (Haliaeetus albicilla). Det är inte alls omöjligt att ett liknande fenomen förekommer på den Svenska kusten inom Östersjön. Det kan finnas orsak att reda ut hur effekterna av ökad predation kunde minskas.

Ytterligare finns det ett klart behov av att revidera uppföljningsprogram så att dessa också omfattar skattning av produktivitet och eventuellt också dödlighet, åtminstone inom de mest betydelsefulla häckningsområdena. På längre sikt borde också andra potentiella orsaker till nedgång som påverkar fåglarna via näringsväven undersökas bättre. Det vore också påkallat att reda ut varför ejdern minskar i Norge. Den uppföljning som görs inom Landskapet Åland (Finland) borde samordnas med den nationella uppföljningen i Finland.

Uppföljning av övervintrande populationer i Östersjön torde gynnas av mer multinationellt samarbete och bättre koordinering. I framtiden borde mer fokus läggas vid de viktiga övervintringsområdena, och en bättre täckning av hela Östersjön. I de viktigaste övervintringsområdena borde en forskningsansats göras för att reda ut det ekologiska tillståndet i dessa områden mer generellt. I en föränderlig värld, där också fåglarna reagerar snabbt (Lehikoinen mfl. (2013), bör man också komma ihåg, att övervintrande dykänder kan flytta till nya områden ifall sådana blir tillgängliga. 


\section{Yhteenveto}

Tässä raportissa arvioidaan viiden Itämerellä pesivän tai talvehtivan sukeltajasorsalajin lukumääräisiä muutoksia. Raportissa käsitellään myös Norjassa ja Islannissa havaittuja trendejä. Raportissa keskitytään lapasotkaan (Aythya marila), haahkaan (Somateria mollissima), alliin (Clangula hyemalis), mustalintuun (Melanitta nigra) sekä pilkkasiipeen (M. fusca). Kaikki lajit ovat voimakkaasti taantuvia uusimman tiedon mukaan, ja niitä yhdistää se, että ne kaikki elävät simpukoiden, erityisesti sinisimpukan (Mytlius edulis x M. trossulus) varassa.

Itämeren rannikoilla pesivien sukeltajasorsien kannoissa voidaan todeta jyrkkä kannan väheneminen lapasotkalla, haahkalla ja pilkkasiivellä niin Suomessa kuin Ruotsissakin. Tanskassa haahkakanta on vakaa. Itämeren ulkopuolella haahka vähenee myös laajalti Norjassa, kun taas Islannin haahkakanta on suhteellisen vakaa. Itämeren rannikon lapasotkakanta ja myös pilkkasiipikanta ovat pieniä, ja erityisesti lapasotka on vaarassa hävitä kokonaan.

Lapasorsan, allin ja mustalinnun sisämaan pesimäkannat sekä Ruotsissa, että Suomessa tuntuvat vakailta, tai ne jopa kasvavat, mutta populaatiot ovat pieniä. Pilkkasiiven sisämaakanta taantuu todennäköisesti Ruotsissa. Norjassa ja Islannissa seurataan ainoastaan haahkakantoja.

Askettäin (Skov ym. 2011) julkaistun raportin mukaan Itämeren talvehtivat sukeltajasorsakannat taantuvat voimakkaasti. Aikavälillä 19881993 ja 2007-2009 kaikki tässä raportissa tarkasteltavat lajit ovat taantuneet noin puolella (50\%), alli jopa $65 \%$. Norjan rannikolla talvehtivat haahkat ja allit ovat niinikään taantuneet. Lapasotkia ei Norjan rannikolla juuri talvehdi, kun taas mustalinnun ja pilkkasiiven kannankehityksessä ei ole selvää suuntausta.

Huolimatta siitä, että Skov ym. (2011) raportissa esitelty aineisto saattaa olla vaikeasti tulkittavissa, raportin yleiset tulokset ovat todennäköisesti luotettavia. Myös muut tiedot tukevat esitettyjen trendien suuntaa, niin pesimäkantojen kehityksen, kuin myös talvehtivien lintujen osalta (vrt. esim. Bellebaum et al. 2014). Skov ym. (2011) esittävät myös lintujen esiintymistä kuvaavaa karttamateriaalia, joka on erittäin käyttökelpoista. Esiintymistietoja voidaan vastaisuudessa käyttää seurannan, tutkimuksen ja kannanhoidon tarpeisiin. Tarpeellista tutkimusta voisi olla pääesiintymisalueiden yleisen ekologisen tilan selvittäminen. 
Seuranta ja tutkimus tulisi järjestää monen valtion koordinoituna yhteistyönä. Talvehtivien sukeltajasorsien kannanmuutokset ovat niin selvät, että olisi varsin perusteltua käynnistää hankkeita, jotka tähtäävät negatiivisen kehityksen pysäyttämiseen.

Kaikkia kansallisia seurantaohjelmia, joiden tulosten varaan tämäkin raportti rakentuu, voitaisiin selvästi parantaa. Tämä koskee sekä sisämaa- että meriympäristöä. Tällä hetkellä voidaan sanoa, että suurella todennäköisyydellä lapasorsa, haahka ja pilkkasiipi taantuvat rannikolla. Näiden lajien osalta pitäisi suuntaukseen puuttua sekä Suomessa, että Ruotsissakin.

Ne taustatekijät jotka aiheuttavat negatiivisen suuntauksen Itämeren pesivien lajien osalta ovat laajalti tuntemattomia. Lapasotkan ja pilkkasiiven vähenemisen syistä ei tarkkaan ottaen tiedetä juuri mitään. Haahkan vähenemiseen vaikuttaa melko varmasti kasvanut saalistuspaine Suomessa, ja se uhka jonka kasvava merikotkakanta (Haliaeetus albicilla) muodostaa, on varteenotettava. Saman ilmiön esiintyminen Ruotsin rannikolla ei ole epätodennäköistä. Olisi paikallaan selvittää miten kasvaneita saalistustappioita haahkakannassa voitaisiin vähentää.

Seurantaohjelmia tulisi myös kehittää, ainakin niin, että niihin sisältyy myös tuottavuuden mittaamista, mahdollisesti myös kuolevuuden mittaamista. Näin tulisi toimia ainakin keskeisillä tuotantoalueilla. Pidemmällä aikavälillä olisi myös syytä selvittää muita suuntauksiin vaikuttavia tekijöitä, jotka voivat olla yhteydessä kunkin lajin ravintoympäristöön. Norjassa tulisi selvittää haahkakannan hupenemisen syitä. Ahvenanmaan Maakunnassa tehtävä seurantatyö tulisi koordinoida Suomen seurantaohjelman kanssa.

Talvehtivien sukeltajasorsakantojen seuranta ja tutkimus hyötyisi yhteistyöstä ja koordinoiduista hankkeista joita toteuttavat useat valtiot yhdessä. Vastaisuudessa tulisi keskittyä tutkimuksessa ja seurannassa keskeisille talvialueille, ja toisaalta laajentaa kattavuutta koko Itämerta koskevaksi. Tärkeimmillä talvialueilla olisi syytä paremmin selvittää ympäristön yleisempi ekologinen tila. Muuttuvassa maailmassa on myös syytä muistaa, että sorsalinnut saattavat ilmaantua talvella uusilla alueilla, jos niitä on tarjolla (Lehikoinen ym. 2013). 
Nordic Council of Ministers

Ved Stranden 18

DK-1061 Copenhagen K

www.norden.org

\section{Trends and drivers of change in diving ducks}

This report addresses changes in population size in five species of diving ducks breeding and wintering in the Baltic Sea. Declines in breeding Greater Scaup, Eider and Velvet Scoters on the Baltic coast are verified. Long-tailed Ducks and Eiders have declined in winter. Breeding Eiders have declined in Norway. Monitoring programs in all Nordic countries are partly inadequate for detecting changes in numbers of birds both in winter and during breeding, but large-scale trends appear reliable. The reasons for the declines observed are largely unknown. For breeding Eiders in the northern part of the Baltic Sea a change in predation regimes on the breeding islands may be important. If the negative trends are to be stopped, a deeper understanding of the drivers involved and better knowledge about the ecological status of the Baltic Sea food webs utilized by the diving ducks are needed.

TemaNord 2015:516

ISBN 978-92-893-3979-7 (PRINT)

ISBN 978-92-893-3981-0 (PDF)

ISBN 978-92-893-3980-3 (EPUB)

ISSN 0908-6692

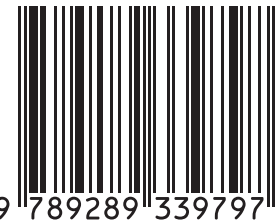

